\title{
Methanogenic Microorganisms in Industrial Wastewater Anaerobic Treatment
}

\author{
Monika Vítězová ${ }^{1}{ }^{1}$, Anna Kohoutová ${ }^{1}$, Tomáš Vítěz ${ }^{1,2, * \mathbb{C}}$, Nikola Hanišáková ${ }^{1}$ and \\ Ivan Kushkevych 1 ,*(D) \\ 1 Department of Experimental Biology, Faculty of Science, Masaryk University, 62500 Brno, Czech Republic; \\ vitezova@sci.muni.cz (M.V.); anna.kohoutova98@seznam.cz (A.K.); hanisakovaniki@sci.muni.cz (N.H.) \\ 2 Department of Agricultural, Food and Environmental Engineering, Faculty of AgriSciences, \\ Mendel University, 61300 Brno, Czech Republic \\ * Correspondence: vitez@sci.muni.cz (T.V.); kushkevych@mail.muni.cz (I.K.); \\ Tel.: +420-549-49-7177 (T.V.); +420-549-49-5315 (I.K.)
}

Received: 31 October 2020; Accepted: 24 November 2020; Published: 26 November 2020

\begin{abstract}
Over the past decades, anaerobic biotechnology is commonly used for treating high-strength wastewaters from different industries. This biotechnology depends on interactions and co-operation between microorganisms in the anaerobic environment where many pollutants' transformation to energy-rich biogas occurs. Properties of wastewater vary across industries and significantly affect microbiome composition in the anaerobic reactor. Methanogenic archaea play a crucial role during anaerobic wastewater treatment. The most abundant acetoclastic methanogens in the anaerobic reactors for industrial wastewater treatment are Methanosarcina sp. and Methanotrix sp. Hydrogenotrophic representatives of methanogens presented in the anaerobic reactors are characterized by a wide species diversity. Methanoculleus sp., Methanobacterium sp. and Methanospirillum sp. prevailed in this group. This work summarizes the relation of industrial wastewater composition and methanogen microbial communities present in different reactors treating these wastewaters.
\end{abstract}

Keywords: wastewater treatment; industrial wastewater; anaerobic reactor; anaerobic digestion; methanogenesis; biogas; microbial community

\section{Introduction}

Today, water is an integral part of the course of our lives, from the operation and maintenance of households to extensive industrial and agricultural use. Ecological, political and ethical aspects today force us to constantly think about streamlining processes and managing natural resources as gently as possible. It is now very important to protect the high quality of water as a renewable resource due to the loss of its share under the surface and in the landscape and watercourses.

Industrial wastewater is an environmental pressure even if these waters are, in some cases, collected by a local sewer system, treated in an urban wastewater treatment plant (UWWTP) and subsequently released to the environment [1]. There are also cases, however, in which these waters are directly released to a water body, generally after treatment at the industrial facility where the wastewater is generated. There is a large and diverse range of economic activities affecting wastewater production. Global data on water uptake per region in 2016 are presented in Figure 1. It shows that industry in Europe is a major consumer of water in relation to other sectors. The global average water uptake by industry is around 19\% [2]. According to the Food and Agriculture Organization of the United Nations (FAO) [3], industrial water uptake in Europe has, however, decreased in recent years. The overall uptake of water by industry is around 200 billion $\mathrm{m}^{3}$ per year, dominated by sea water abstraction for cooling systems, which uses around 50 billion $\mathrm{m}^{3}$ per year. Water uptake for industrial 
manufacturing processes (not cooling) has experienced a 40\% reduction in Europe since 1990 (from around 50 to 30 billion $\mathrm{m}^{3}$ per year).

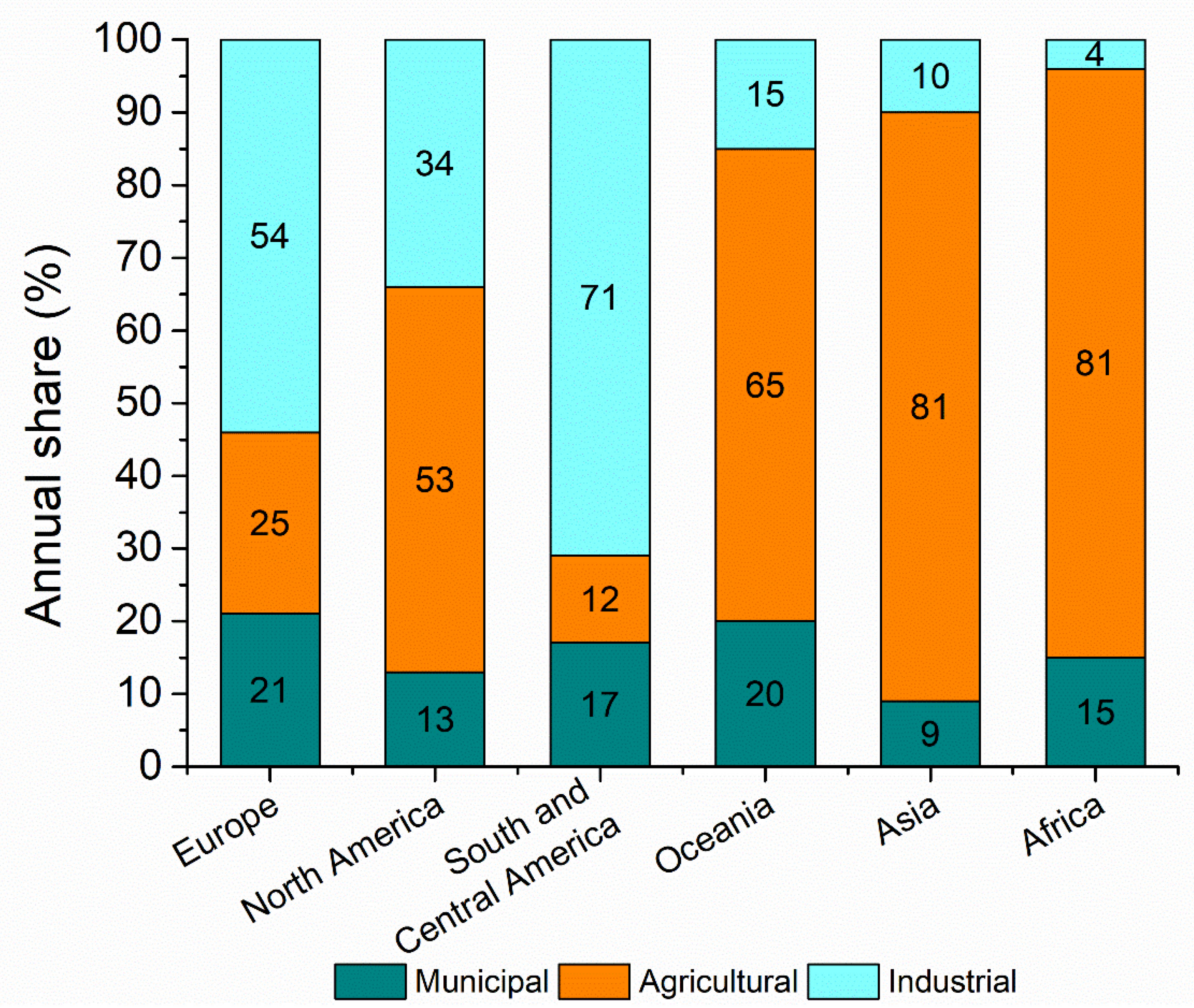

Figure 1. Annual share of global water uptake by activity and region [2], revised by authors.

The release of industrial wastewater is regulated in Europe both directly as part of the environment law on industry and indirectly by the EU policies that tackle water issues horizontally. Industrial wastewater generation and management is regulated by Water Framework Directive (WFD, 2000/60/EC). Industry's direct or indirect releases of pollution to the environment are among the key aspects regulated by the Industrial Emissions Directive (IED, 2010/75/EU). Currently, the IED regulates 31 industrial sectors and over 50,000 installations in Europe. To meet the legislation requirements, an approach known as best available techniques (BAT) is adapted. To specify processes and activities for individual industrial sectors, BAT reference documents (BREFs) are used.

The anaerobic wastewater treatment system has been known and used since the end of the 19th century [4]. Systematic research work and deeper anaerobic process understanding caused anaerobic digestion (AD), a biological process in which organic matter is converted to $\mathrm{CH}_{4}$ and $\mathrm{CO}_{2}$, to become a more attractive technology for wastewater treatment due to its low capital and operation cost compared to the other technologies available in last decades. Today, anaerobic techniques are generally utilized in industries with high level of soluble and readily biodegradable organic material. Many types of industrial wastewaters believed to be unsuitable for anaerobic treatment are today treated with advanced anaerobic reactor systems [5]. The role of microorganisms and their formation into complex communities is an essential pillar of the whole anaerobic biotechnology, but so far there are few laboratories and publications that deal with this issue in detail. Interactions between microorganisms, their co-operation or competition, with other aspects, have a significant impact on the final functionality of the whole process. Therefore, in addition to an external understanding of processes and technological parameters, it is important to examine the composition of microbial communities. Awareness of the general composition of the microbial community may be very important in the future for the typing of anaerobic biotechnologies, their implementation in industrial areas and the potential solution of functional defects and problems. 
The main objective of this study was to investigate the complex issues of the composition of microbial communities in anaerobic reactors, especially in relation to the composition of wastewater. This review contains a basic description of anaerobic technology and the composition of selected types of industrial wastewater. It summarizes information on the occurrence of microorganisms and tries to define the composition of methanogenic communities' present in this environment.

\section{Industrial Wastewater}

\subsection{Industrial Wastewater Types}

Industrial wastewater varies in composition and cannot be simply characterized. Three major types of wastewater can be defined, processing, cleaning and sanitary. Different industrial sectors generate different compositions and quantities of these wastewaters at the effluent [6]. It may be highly biodegradable or not at all and may or may not contain compounds recalcitrant to treatment. The main concern with industrial wastewater is the increasing amount (in quantity and variety) of synthetic compounds contained in and discharged to the environment. The main industrial wastewater types are presented in Table 1.

Table 1. Industrial wastewater types depending on the industrial sectors [7], edited by the authors.

\begin{tabular}{|c|c|c|c|}
\hline Category & Common Features & Pollutants & Typical Industrial Sectors \\
\hline $\begin{array}{l}\text { Minimal contamination (can be } \\
\text { land spread) }\end{array}$ & $\begin{array}{l}\text { Wastewater contains no pollutants, nutrients } \\
\text { can be useful for agricultural plants } \\
\text { development, levels of toxic substances is } \\
\text { very low }\end{array}$ & Nitrogen, phosphorus & Food and drink \\
\hline $\begin{array}{l}\text { Equivalent to } \\
\text { domestic-type effluents }\end{array}$ & $\begin{array}{l}\text { Organic pollutants similar content as in } \\
\text { municipal wastewater }\end{array}$ & Degradable organic matter & Food and drink \\
\hline $\begin{array}{l}\text { Low flow and non-domestic } \\
\text { type pollutants at low } \\
\text { concentrations }\end{array}$ & $\begin{array}{l}\text { Wastewater containing small concentrations of } \\
\text { other pollutants not present in urban effluents }\end{array}$ & $\begin{array}{l}\text { Pesticides, hormones, } \\
\text { nano-plastics and endocrine } \\
\text { disrupters }\end{array}$ & Chemicals \\
\hline Metals & $\begin{array}{l}\text { Wastewater containing metals or metalloids } \\
\text { from industry }\end{array}$ & Metals & $\begin{array}{l}\text { Metal processing and mineral } \\
\text { industry }\end{array}$ \\
\hline High nutrient loading & $\begin{array}{l}\text { Wastewater containing high concentrations of } \\
\text { nitrogen compounds, phosphates, with higher } \\
\text { conductivity }\end{array}$ & $\begin{array}{l}\text { Substances increasing } \\
\text { eutrophication }\end{array}$ & Chemicals: fertilizers \\
\hline $\begin{array}{l}\text { Effluent streams requiring } \mathrm{pH} \\
\text { adjustment }\end{array}$ & $\begin{array}{l}\text { Wastewater streams with very low or very } \\
\text { high } \mathrm{pH}\end{array}$ & Acids or alkalis & Chemicals and mineral industry \\
\hline Persistent organics content & $\begin{array}{l}\text { Wastewater containing not easily degradable } \\
\text { organic pollutants (persistent hydrocarbons or } \\
\text { bioaccumulative organic toxic substances }\end{array}$ & Persistent organics & Textiles and chemicals \\
\hline Emerging substances & $\begin{array}{l}\text { Wastewater contains new pollutants or has } \\
\text { characteristics that are not currently monitored }\end{array}$ & $\begin{array}{l}\text { New parameters or compounds } \\
\text { not frequently measured }\end{array}$ & Pharmaceuticals \\
\hline
\end{tabular}

\subsection{Industrial Water Suitable for Anaerobic Treatment and Methane Production}

Anaerobic techniques are typically used for high-loaded wastewaters, expressed in chemical oxygen demand (COD), typically greater than $1500-2000 \mathrm{mg} / \mathrm{L}$. The application of anaerobic wastewater treatment is largely confined to relatively heavily polluted wastewater with a COD between 3000 and 40,000 mg/L, e.g., in the sugar, starch, fruit and vegetable and alcoholic drinks sectors. There has recently been some success in using certain anaerobic systems even for less heavily polluted wastewater with a COD between 1500 and $3000 \mathrm{mg} / \mathrm{L}$, e.g., in breweries, dairies and in the fruit juice, mineral water and the soft drinks sectors. Some success in using anaerobic systems for less polluted wastewater with a COD lower than $1500 \mathrm{mg} / \mathrm{L}$ was reported [7-9]. It is clear that only industrial wastewater with significant carbon loading that is treated under intended or unintended anaerobic conditions will produce methane [10]. Assessment of methane production potential from industrial wastewater streams is based on the concentration of biodegradable organic matter in the wastewater, Tables 2 and 3 [11,12], edited by the authors. 
Table 2. Chemical compounds amenable to anaerobic biotechnology.

\begin{tabular}{cccc}
\hline Acetaldehyde & Crotonic acid & Isobutyric acid & Isopropyl alcohol \\
Acetic anhydride & Diacetone gulusonic acid & Isopropanol & Propionate \\
Acetone & Dimethoxy benzoic acid & Lactic acid & Propylene glycol \\
Acrylic acid & Ethanol & Maleic acid & Protocatechuic acid \\
Adipic acid & Ethyl acetate & Methyl acetate & Resorcinol \\
Aniline & Ethyl acrylate & Methyl acrylate & Sec-butanol \\
1-amino-2-propanol & Ferulic acid & Methyl ethyl ketone & Sec-butylamine \\
4-amino butyric acid & Formaldehyde & Methyl formate & Sorbic acid \\
Benzoic acid & Formic acid & Nitrobenzene & Syringaldehyde \\
Butanol & Fumaric acid & Pentaerythritol & Syringic acid \\
Butyraldehyde & Glutamic acid & Pentanol & Succinic acid \\
Butylene glycerol & Glutaric acid & Phenol & Tert-butanol \\
Catechol & Glycerol & Phthalic acid & Vanillic acid \\
Cresol & Hexanoic acid & Propanal & Vinyl acetate \\
Crotonaldehyde & Hydroquinone & Propanol & \\
\hline
\end{tabular}

Table 3. Industrial wastes amenable to anaerobic digestion.

\begin{tabular}{cccc}
\hline Agriculture wastes & Corn processing wastes & Chemical industry wastes & Seafood and shellfish wastes \\
Alcohol stillage & Dairy wastes & Meat packing wastes & Slaughterhouse and meat packing \\
Animal wastes & Egg processing wastes & Pear wastes & Sugar processing wastes \\
Bagasse & Fruit Leachate & Peat wastes & Tannery wastes \\
Bean blanching water & Giant kelp wastes & Pectin wastes & Vegetable processing wastes \\
Beverage production wastes & Guar gum wastes & Petroleum wastes & Wheat and grain processing wastes \\
Brewery wastes & H2-CO pyrolysis wastes & Pharmaceutical & Wine processing wastes \\
Canning wastes & Heat-treated activated sludge & Potato processing wastes & Wood processing wastes \\
Coking mill wastes & Cheese processing wastes & Pulp and paper wastes & Wool scouring wastes \\
\hline
\end{tabular}

The volume of wastewater, and the propensity of the industrial sector to treat their wastewater in anaerobic systems are also important. Using these criteria, major industrial wastewater sources with high methane production potential can be identified as follows:

- Meat and poultry processing (slaughterhouses)

- Alcohol, beer, starch production

- Pulp and paper manufacture

- Chemical industry waste

- $\quad$ Other food and drink processing (dairy products, vegetable oil, fruits and vegetables, canneries, juice making, etc.)

Recent development and knowledge showed that anaerobic processes might be an economically feasible alternative for different types of industrial wastewaters treatment. The number of wastes that are amenable to anaerobic digestion is quite large (Tables 2 and 3). However, the feasibility of the anaerobic digestion of an industrial waste is determined by several factors. These factors are waste concentration; waste stream temperature; anaerobic process inhibitors presence in waste stream; expected biogas yield and treatment efficiency [11]. The anaerobic process has many advantages over conventionally used and proven aerobic processes. The most significant positive of the technology is the fact that energy is generated in the form of biogas by means of anaerobic decomposition from unnecessary waste in the form of pollutants in the wastewater.

\subsection{Composition of Selected Industrial Wastewater}

The composition of industrial wastewater will be characterized by both the substance load and the proportion of biodegradable substances and the values of other, more specific parameters (Table 4). 
Table 4. Composition characteristics of individual industrial wastewaters (values are given in $\mathrm{mg} / \mathrm{L}$ except $\mathrm{pH}$ ).

\begin{tabular}{|c|c|c|c|c|c|c|c|c|c|c|}
\hline Wastewater Type & COD & BOD & TS & SS & vSS & $\mathrm{TN}$ & TP & $\mathrm{N}-\mathrm{NH}_{4}{ }^{+}$ & $\mathrm{pH}$ & Reference \\
\hline Slaughterhouse & $2000-11,588$ & $1300-4635\left(\mathrm{BOD}_{5}\right)$ & 6394 & $850-6300$ & $660-5250$ & 850 & $15-48$ & $20-66$ & $6.3-6.98$ & {$[13,14]$} \\
\hline Poultry slaughterhouse & $2790-5520$ & $1558-2988$ & - & - & - & $62-313(\mathrm{KN})$ & - & $16-95$ & $6.8-7.8$ & [15] \\
\hline Poultry processing & 1140 & $570\left(\mathrm{BOD}_{5}\right)$ & - & 264 & - & - & - & 2.7 & - & [16] \\
\hline Meat processing & 5160 & - & 2028 & 1820 & 1380 & - & - & - & 7.5 & [17] \\
\hline Livestock breeding & $6190-78,600$ & $3940-34,600$ & - & $1850-29,000$ & - & $1530-6500$ & $116-1770$ & - & - & [18] \\
\hline Dairy industry & - & $10,000-50,000$ & - & $220-340$ & $200-300$ & 188 & 100 & 18 & 9-10.5 & [19] \\
\hline Milk plant & $2000-6000$ & $1200-4000\left(\mathrm{BOD}_{5}\right)$ & - & $350-1000$ & $330-940$ & $50-60(\mathrm{KN})$ & - & - & $8.0-11.0$ & [20] \\
\hline Butter production & 52,000 & - & - & 1500 & - & $1120(\mathrm{KN})$ & - & - & $4.3-5.9$ & {$[20,21]$} \\
\hline Brewery & 2000-6000 & $1200-3600$ & $5100-8750$ & $2901-3000$ & - & $25-80(\mathrm{KN})$ & $10.0-50.0$ & - & $3.0-12.0$ & [22] \\
\hline Raw distillery wastewater & $80,000-120,000$ & $45,000-60,000$ & 100,000 & 10,000 & $100-2800$ & $100-64,000$ & $240-65,000$ & - & $3.5-5.2$ & {$[23,24]$} \\
\hline Sugar factory & $572-6612$ & - & $3840-5780$ & $30-170$ & $560-6470$ & - & $2.0-4.0$ & $3.7-10.1$ & $4.7-5.2$ & [25] \\
\hline Cellulose Processing & $600-10,400$ & $221-3700$ & - & $20-3200$ & - & - & - & - & $6.3-9.0$ & [26-28] \\
\hline Fruits and Vegetables Processing & $1500-4300$ & $500-2500$ & $400-1200$ & & & & & & 6-10 & [29] \\
\hline Vegetable oil mills & 1355-1987 & $712-1136\left(\mathrm{BOD}_{5}\right)$ & - & - & - & - & - & $3.6-14.4$ & $0.9-2.3$ & [30] \\
\hline Olive oil mills & 57,200 & - & 49,100 & - & - & 1600 & 300 & - & 4.9 & [31] \\
\hline Refining of vegetable oils & $17,688-24,787$ & $4120-4560\left(\mathrm{BOD}_{5}\right)$ & - & 791-3544 & - & $<10$ & - & $<10$ & $10.0-10.4$ & [32] \\
\hline Blackberry processing & 930 & - & 840 & - & - & 92 & - & - & 5.9 & [33] \\
\hline Dates processing & 410 & - & 471 & - & - & 37 & - & - & 6.1 & [33] \\
\hline Tomato processing & 294 & - & 322 & - & - & 21 & - & - & 5.3 & [33] \\
\hline Beetroot processing & 501 & - & 630 & - & - & 43 & - & - & 6.2 & [33] \\
\hline Butadiene and styrene & $800-1500$ & $4000-8000\left(\mathrm{BOD}_{5}\right)$ & - & $200-500$ & - & - & - & - & - & [34] \\
\hline Acrylates & $2000-3200$ & $1000-2000\left(\mathrm{BOD}_{5}\right)$ & - & $50-100$ & - & - & - & - & - & [34] \\
\hline Acetaldehyde & $40,000-60,000$ & $15,000-25,000\left(\mathrm{BOD}_{5}\right)$ & - & $150-300$ & - & - & - & - & - & [34] \\
\hline Ketones & $20,000-40,000$ & $10,000-20,000\left(\mathrm{BOD}_{5}\right)$ & - & 50-100 & - & - & - & - & - & [34] \\
\hline Methyl acrylate acid & $7000-12,000$ & - & - & $6000-12,000$ & - & - & - & - & - & [34] \\
\hline Organic acids & $5000-15,000$ & $300-600\left(\mathrm{BOD}_{5}\right)$ & - & $100-200$ & - & - & - & - & - & [34] \\
\hline $\begin{array}{l}\text { Raw materials for the } \\
\text { pigment industry }\end{array}$ & $1000-2000$ & $200-400$ & - & $80-200$ & - & - & - & - & - & [34] \\
\hline
\end{tabular}

BOD—biochemical oxygen demand; COD—chemical oxygen demand; TS—-total solids; SS—suspended solids; VSS—volatile suspended solids; TN—total nitrogen; TP—total phosphorus. 


\section{Anaerobic Wastewater Treatment}

\subsection{Aerobic Versus Anaerobic Wastewater Treatment}

Today, aerobic biological wastewater treatment processes are increasingly used in connection with the anaerobic sewage sludge stabilization in large and medium wastewater treatment plants. In the last decades, anaerobic digestion has grown more and more into an attractive technology for wastewater treatment due to its low capital and operation costs compared to the other technologies available: physicochemical and aerobic biological treatments. Here, practice has shown that anaerobic sludge and wastewater treatment as biological treatment has recently increasingly appeared to be a more environmentally friendly and economical process, both in terms of the formation of excess sludge and the conversion of the substrate to biogas [35]. Substantial savings, reaching 90\% in operational costs as no energy is required for aeration and a 40-60\% reduction in investment cost, are reported. Produced $\mathrm{CH}_{4}$ can be used for energy recovery or electricity production, excess sludge production is low, and sludge is well stabilized and easily dewatered, so extensive post treatment is not required [36]. When aerobic and anaerobic treatment is compared, some advantages which bring appropriate application of anaerobic technology can be found (Table 5). Anaerobic treatment produces up to ten times less biomass, which is related to very low requirements for nutrients and energy in the form of biogas. Excess sludge does not need to be further stabilized, which is a necessary part of aerobic treatment [37].

Table 5. Basic comparison of aerobic and anaerobic treatment $[36,38]$.

\begin{tabular}{|c|c|c|}
\hline & Aerobic Treatment & Anaerobic Treatment \\
\hline Transformation of input substrate & $\begin{array}{c}50 \% \text { microbial biomass } \\
50 \% \mathrm{CO}_{2}\end{array}$ & $\begin{array}{c}5 \% \text { microbial biomass } \\
95 \% \text { biogas }\end{array}$ \\
\hline Energy balance & $\begin{array}{c}60 \% \text { microbial biomass } \\
40 \% \text { reaction heat }\end{array}$ & $\begin{array}{c}90 \% \text { biogas } \\
5-7 \% \text { microbial biomass } \\
3-5 \% \text { reaction heat }\end{array}$ \\
\hline
\end{tabular}

From the bioreactor and the overall cleaning process point of view, anaerobic wastewater purification is an alternative to aerobic technologies. The anaerobic process has mainly been used for sewage sludge stabilization. However, research [39] has showed that industrial wastes can also be treated by anaerobic processes. Young and McCarty [40] found that low-strength soluble organic wastes can also be efficiently treated anaerobically.

In anaerobic reactors, a high concentration of biomass is still maintained, which is related to the ability to treat wastewater with a very high material load. On the other hand, anaerobic microorganisms grow very slowly, which is why it is still necessary to maintain their high concentration and leave the substrate in the anaerobic reactor for a long time $>15$ days [11,41]. However, one of the biggest advantages of this is that the high sludge retention time in the reactor promotes the growth of microorganisms with a long generation time, which are able to degrade pollutants that cannot be degraded in aerobic conditions or are toxic to aerobic microorganisms. Finally, we cannot omit the price of operation, which is significantly lower for anaerobic technologies [37].

It should be noted that anaerobic treatment also has its disadvantages. The total loss of organic matter is still not achieved in anaerobic processes and it is often necessary to treat the wastewater aerobically. Another major disadvantage is the high sensitivity of anaerobic organisms, especially methanogenic archaea, and their long generation time, which is associated with a long time to start the operation of reactors [36].

\subsection{Anaerobic Digestion}

Anaerobic digestion is a promising biotechnology for wastewater that is highly organically polluted and therefore contains high concentrations of biodegradable substances [36]. The digestion 
of substrate in anaerobic reactors results in the significant reduction in the volatile solids content as well as the volume and weight of the substrate. Figure 2 shows the fate of volatile solids during anaerobic digestion.

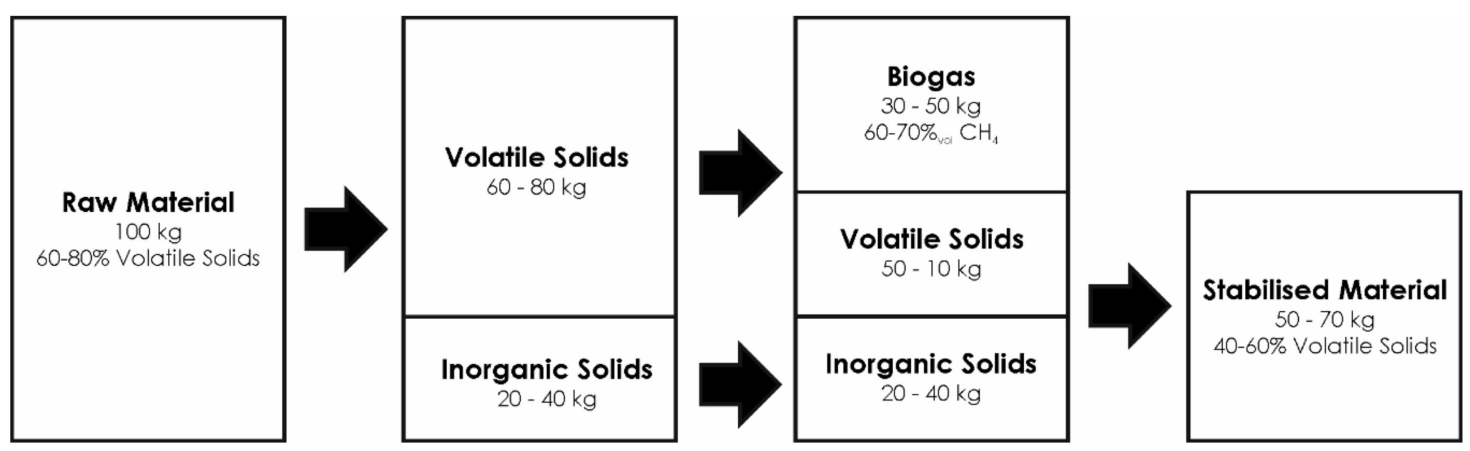

Figure 2. Volatile solids balance during anaerobic digestion.

Anaerobic digestion is a complex process (Figure 3) that consists of a number of biochemical processes and is mediated by systematically interconnected microorganisms mainly from the Bacteria and Archaea domains [42] and also to a lesser extent by Eukaryotes and a very small percentage of viruses [43]. By means of individual biochemical transformations, complex organic compounds are decomposed into as many oxidized and reduced forms of carbon as possible, i.e., carbon dioxide and methane [44].

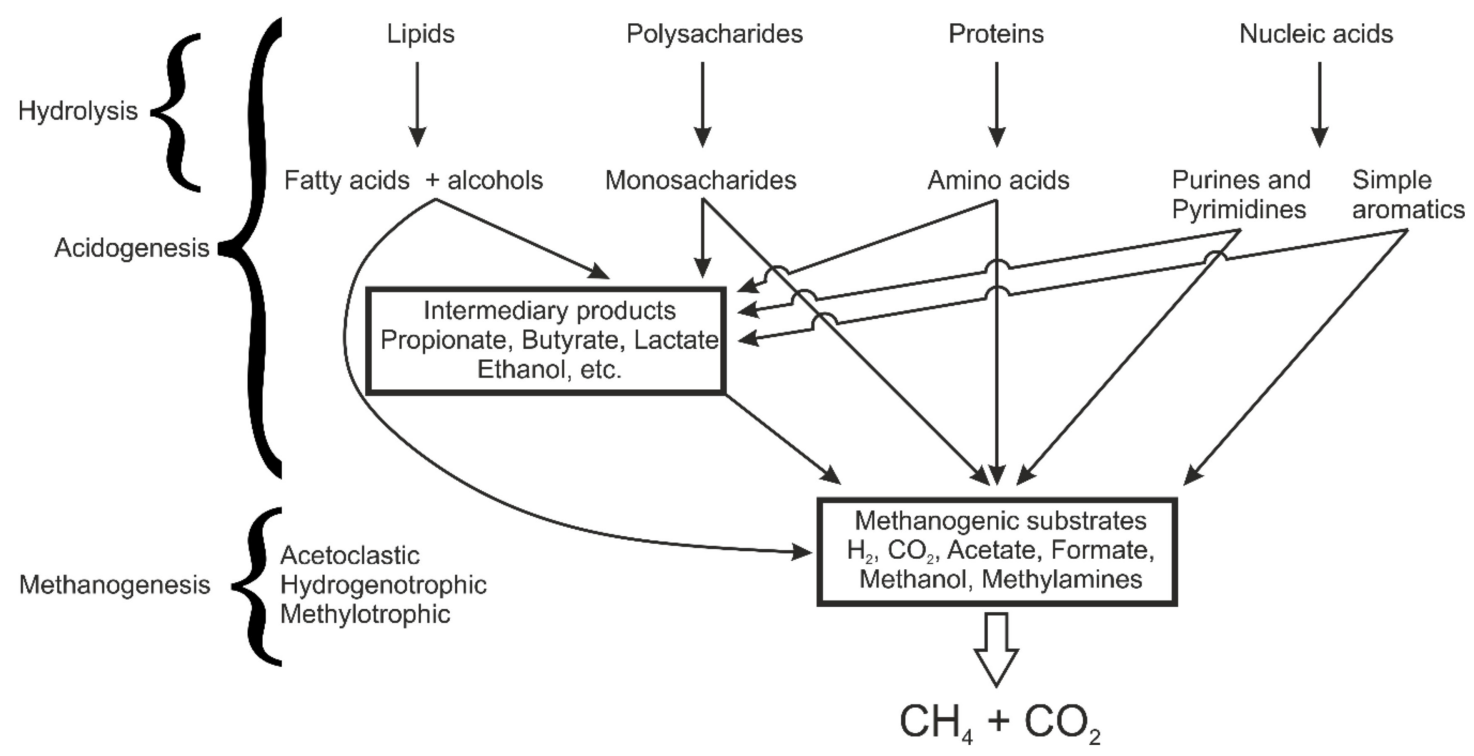

Figure 3. Scheme of reactions during anaerobic decomposition of polymeric materials [45], edited by authors.

During hydrolysis, the complex biopolymers are cleaved by extracellular enzymes of fermentative bacteria into smaller parts, monomers, which are further able to process the bacteria directly in the cell. Fermentative bacteria convert monomers mainly into volatile fatty acids such as butyric, acetic and propionic acids or alcohols, lactic acid and molecular hydrogen during acidogenesis. Most of these bacteria are obligate anaerobes, but some facultative anaerobes may be present. During acidogenesis, acetate, carbon dioxide and molecular hydrogen are formed from the already mentioned volatile fatty acids. Hungate [46] was the first to show that hydrogen production and utilization can influence the anaerobic digestion. In addition, acetate can also be formed by homoacetogenesis, i.e., from carbon dioxide and hydrogen. Bryant [47] pointed out that the products of the hydrolysis other than 
acetate, $\mathrm{H}_{2}$ and $\mathrm{CO}_{2}$, i.e., alcohols, propionate and longer-chain fatty acids and aromatic acids are anaerobically oxidized to acetate or acetate and $\mathrm{CO}_{2}$ by a group of $\mathrm{H}_{2}$-producing acetogenic bacteria. During methanogenesis, methane is formed by three major pathways-acetoclastic, hydrogenotrophic and methylotrophic-by methanogenic archaea $[36,48]$. All processes in the anaerobic bioreactor run in parallel after the equilibrium has been established.

The anaerobic process usually takes place in mesophilic $\left(35-50{ }^{\circ} \mathrm{C}\right)$ or thermophilic $\left(50-60{ }^{\circ} \mathrm{C}\right)$ cultures of microorganisms, and, in terms of biogas yield, thermophilic cultures show higher biogas production. The biogas produced consists mainly of carbon dioxide and methane. Typical methane content in biogas ranged from 50 to $85 \%$ vol. Other gases $\left(\mathrm{H}_{2} \mathrm{~S}, \mathrm{NH}_{3}\right.$ and water vapor) are usually present in biogas in the hundreds or thousands of ppm.

In addition to methanogenic communities, bioreactors can also contain bacteria that can compete with methanogens for the available substrate and thus negatively affect biogas production. These are facultatively anaerobic bacteria that can use molecular oxygen as an electron acceptor, denitrifying bacteria that use nitrates, sulfate-reducing bacteria (SRB) using sulfides and sulfates, or bacteria that reduce iron ions [36]. Recent research demonstrates strong competition between methanogenic archaea and SRB for molecular hydrogen. These are mainly hydrogenotrophic methanogens, which use hydrogen to reduce the methyl group to methane. Reducing the metabolic activity of SRB could contribute to improving the quality of biogas. Hydrogen sulfide is known to corrode the engines of cogeneration units for electricity producing [49].

\subsection{Anaerobic Bioreactors}

Anaerobic processes for the treatment of wastewaters and sludges are well over 100 years old [50]. In the last 50 years, anaerobic reactor technology evolved from localized lab-scale trials to worldwide successful implementations at a variety of industries [51]. The occurrence of the new environmental laws within the EU, tightening limits for discharged water, increased prices for energy and final sludge disposal, and a high amount of highly strengthened wastewater from industry accelerated development in anaerobic reactor technology. Since the 1970s, when Lettinga et al. [52] first described the Upflow Anaerobic Sludge Blanket (UASB) process, a lot of progress has been made in the anaerobic wastewater treatment. The development of the high-rate generation of anaerobic reactors took place in the 1980s, with the aim to decrease the hydraulic retention time; this was the main weakness of anaerobic reactors in that time. Since the 1990s, the development and application of anaerobic reactors for simultaneous treatment and methane production have found considerable success [31]. Today, different types of high-rate anaerobic reactors characterized by short hydraulic retention time, high pollutant removal efficiency and high applicable volumetric loading rates are commonly used across the industry worldwide. A total of 2360 full-scale installations were in operation in 2019 based on author surveys of the following renowned vendors: PAQUES (Biopaq); VEOLIA (Biothane); WATERLEAU (Biotim); GLOBAL WATER \& ENERGY (ANUBIX and ANAFIX); EVOQUA (ADI); KURITA; SUEZ (Degremont); ENVIROCHEMIE (Biomar); HYDROTHANE (HydroThane). Such vendors are mainly in the food and beverage industry (Figure 4). The data also showed that UASB was the most common type of reactor followed by Internal Circulation (IC) and Expanded Granular Sludge Bed (EGSB). These types of reactors represent in total $89 \%$ of all reactors installed (Figure 5). 


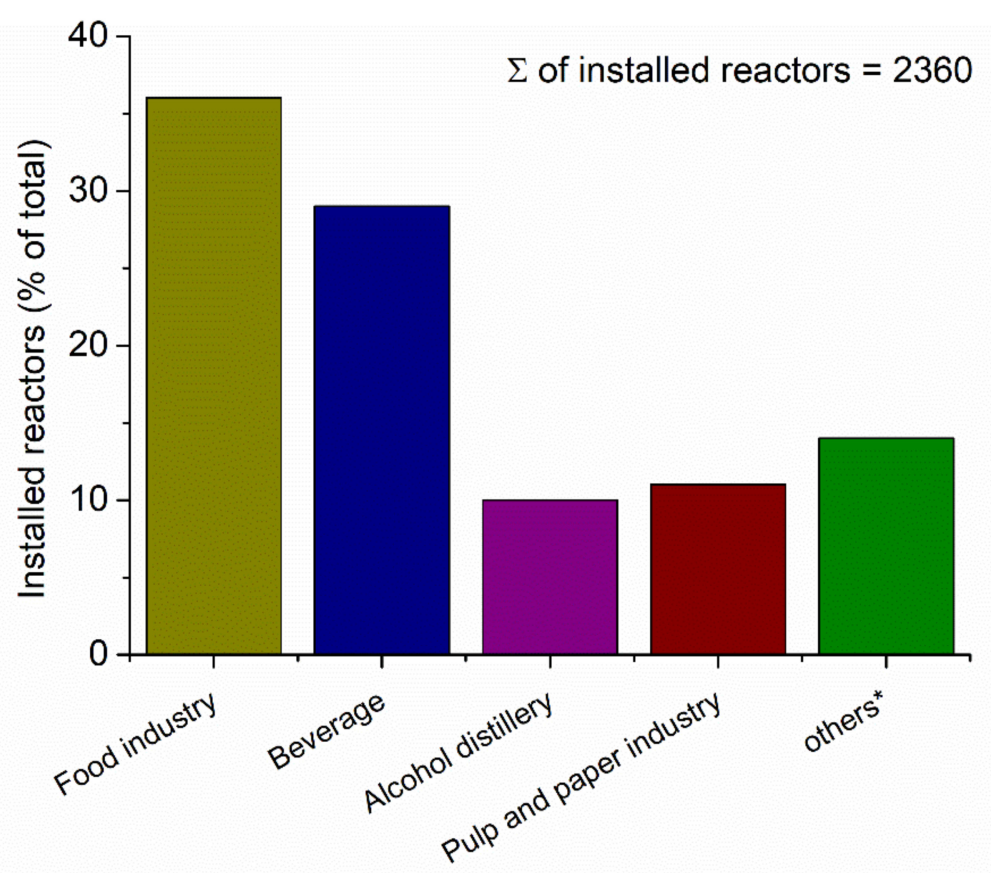

Figure 4. Application of anaerobic technology to industrial wastewater. Total number of registered installed reactors $=2360$; ${ }^{*}$ chemical, pharmaceutical, sludge liquor, landfill leachate, acid mine water, municipal sewage; adopted from [53] and updated and edited by the authors.

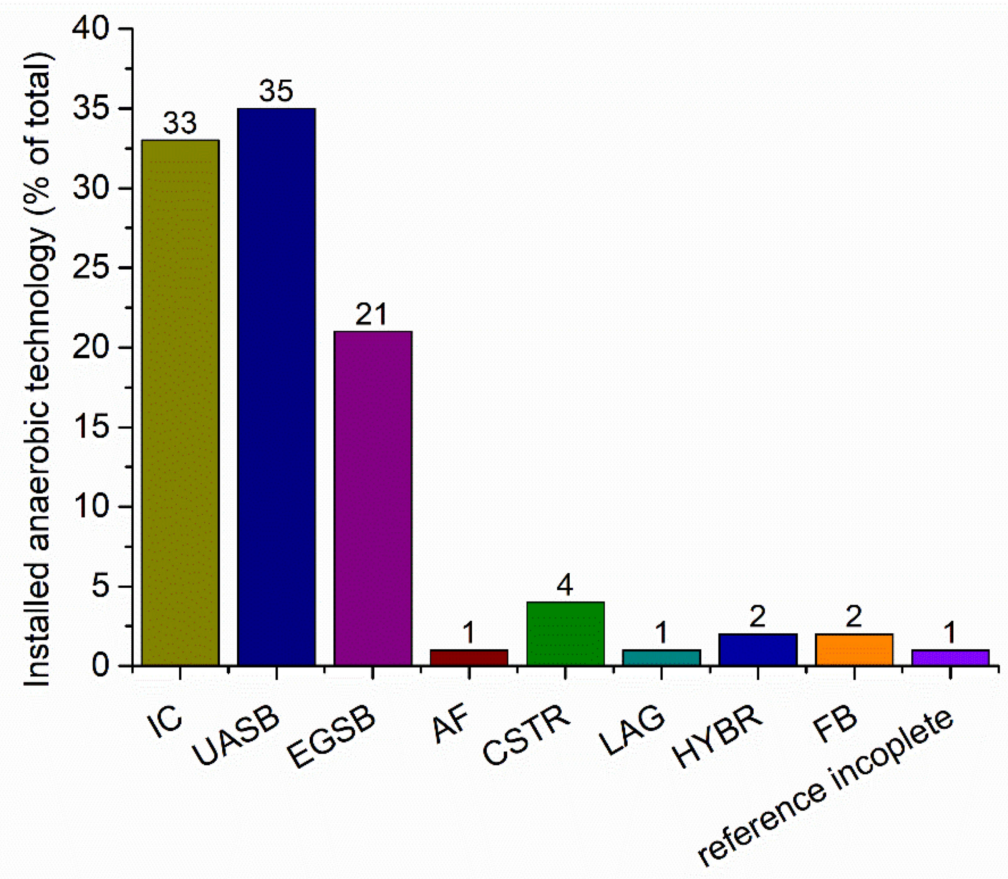

Figure 5. Implemented anaerobic technologies for industrial wastewater pictured for the period 2002-2019. IC: Internal Circulation; UASB: Upflow Anaerobic Sludge Blanket; EGSB: Expanded Granular Sludge Bed; AF: Anaerobic Filter; CSTR: Continuously Stirred Tank Reactor; LAG: anaerobic lagoon; HYBR: combined system with sludge bed at the bottom section and a filter in top; FB: fluidized bed reactor; adopted from [36], updated and edited by authors.

Anaerobic bioreactors initial drawbacks (biomass slow growth rate, susceptibility to toxic compounds, huge reactors volumes, etc.) were overcome. The new generation of reactors with a short hydraulic retention time (HRT) ( $2 \mathrm{~h}$ to $48 \mathrm{~h}$ ) and the ability to process high organic loading 
rates ( 4 to $40 \mathrm{~kg} \mathrm{COD} / \mathrm{m}^{3}$ reactor per day) was developed (Table 6 ). In these reactors, the problem of slow growth rate was turned by capturing the biomass in the form of biofilms on static or moving supports but also by selecting well settling flocculating biomass. This development resulted in much smaller reactors volume but also in a much more stable operation than before.

Table 6. Typical processes and performance data of anaerobic technologies used for industrial wastewater treatment [39,54].

\begin{tabular}{ccccc}
\hline Process & Inflow COD & $\begin{array}{c}\text { Hydraulic } \\
\text { Retention Time }\end{array}$ & Organic Loading Rate & $\begin{array}{c}\text { COD } \\
\text { Removal } \\
\text { Efficiency }\end{array}$ \\
\hline & $\mathbf{( m g / L )}$ & $\mathbf{( h )}$ & $\mathbf{~ k g}_{\text {COD }} / \mathbf{m}^{3}$ per day) & $\mathbf{( \% )}$ \\
\hline Anaerobic lagoons & N.A. & $24-1200$ & $0.04-1$ & $30-50$ \\
Anaerobic contact process & $1500-5000$ & $2-14$ & $0.5-5.3$ & $75-90$ \\
$\quad \begin{array}{l}\text { Fixed Bed reactor } \\
\text { Upflow Anaerobic Sludge } \\
\text { Blanket (UASB) reactor } \\
\text { Expanded Granular }\end{array}$ & $10,000-70,000$ & $24-48$ & $1-15$ & $75-85$ \\
$\begin{array}{c}\text { Sludge Bed (EGSB) reactor } \\
\text { Internal Circulation } \\
\text { (IC) reactor }\end{array}$ & $5000-90,000$ & $4-12$ & $4-12$ & $75-85$ \\
\hline
\end{tabular}

Anaerobic bioreactors for wastewater treatment can be divided in terms of the biomass cultivation of microorganisms. Biomass can be cultured in suspension or it can form the biofilm. Anaerobic reactors with suspension culture are particularly suitable for the treatment of wastewater with a high proportion of suspended solids. By constant homogenization of the sludge, a good access of microorganisms to the substrate is achieved. Reactors with biomass cultivation in biofilm can be further divided into reactors with fixed and moving charge. The two technologies differ only in the carrier on which the biomass forming the biofilm is captured, namely the solid and the fluid or expanded carrier. Biofilm anaerobic reactors are then modified in terms of wastewater flow or rotation. Most widespread technologies for anaerobic wastewater treatment reactors are upflow Anaerobic Sludge Blanket Process (UASB), Internal Circulation (IC) and Expanded Granular Sludge Bed (EGSB) (Figure 6A-C). The UASB reactor is a suspended-growth reactor that maintains a very high concentration of microbial biomass by promoting granulation. The anaerobic granules are 1-3 $\mathrm{mm}$ in diameter and dense enough to settle down in the reactor. The biomass concentration in the UASB reactor reaches $50 \mathrm{~g} / \mathrm{L}$ or higher and thus maintains a very long sludge retention time $>15$ days irrespective of the short hydraulic retention time of 4-12 h. Upflow velocity typically ranges from 0.5 to $1.0 \mathrm{~m} / \mathrm{h}, 4.5$ to $6.5 \mathrm{~m}$ high [41]. The EGSB reactor was developed from UASB reactors. It has a high recycle ratio, and the upflow of this reactor is typically maintained higher than $6 \mathrm{~m} / \mathrm{h}, 12$ to $16 \mathrm{~m}$ high [41]. The IC reactor is a new concept being mostly used for the treatment of industrial effluents of high strength. The higher OLR of the IC reactor is mainly due to its internal circulation, which allows for an improved contact between the biomass and the influent [41].

In the case of granular biomass reactors, the microorganisms combine to form granules of different color, density and size. The granules are present in different proportions and the microorganisms that are part of them can play various roles in anaerobic processes. It is also important to note that, across the types of these granules, the methanogenic archaea forms a core, more or less active, and bacteria form the outer layers of the granules [55].

Many reactors operate despite the same names on the same or similar principles. Due to the evolving technology, only specific modifications are made to the basic structures due to several design companies. The potential of anaerobic reactors in wastewater treatment is now great but will increase as the parameters are unified and the technology is universalized. 
(A)

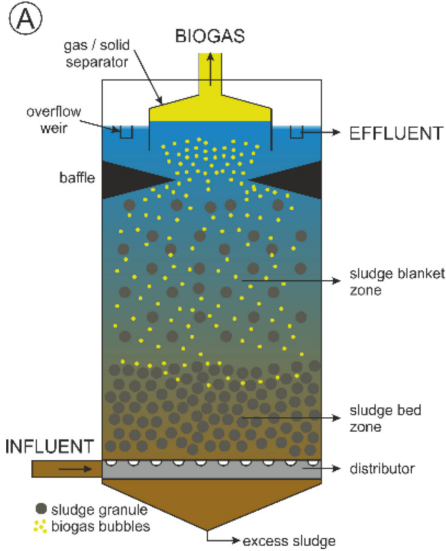

(B)

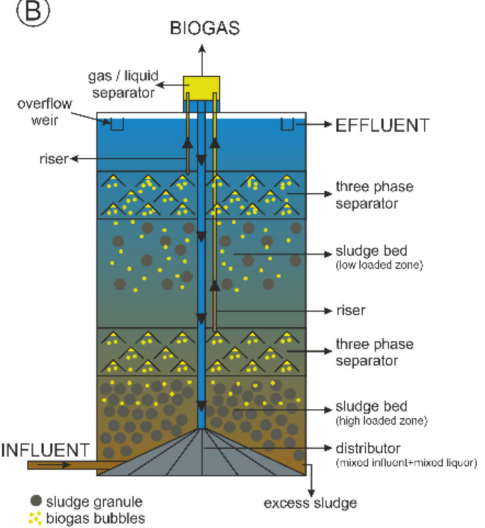

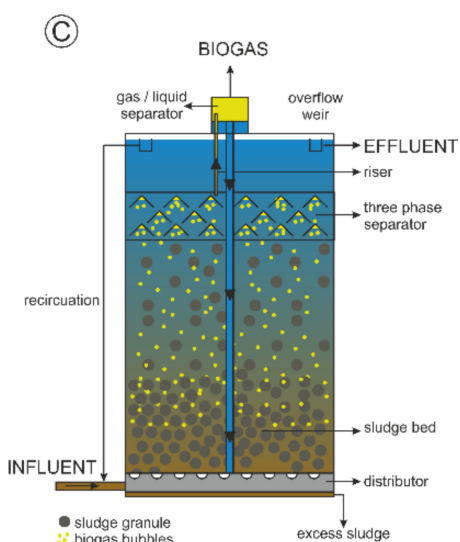

Figure 6. Scheme of an Upflow Anaerobic Sludge Blanket (UASB) reactor (A), an Internal Circulation (IC) reactor (B) and an Expanded Granular Sludge Blanket (EGSB) reactor (C).

\section{Methanogenic Microorganisms in Industrial Wastewaters}

The composition of microorganisms in anaerobic bioreactors will be affected by many factors. These are reactor design, temperature, $\mathrm{pH}, \mathrm{C}: \mathrm{N}$ ratio, wastewater composition, organic loading rate, hydraulic retention time, and agitation [11]. A very important fact is that anaerobic bioreactors during start up are usually seeded with inoculum from other biotechnology. A wide range of anaerobic bacteria are reported inhabiting anaerobic fermenters. These belongs mainly to the Proteobacteria, Firmicutes, Actinobacteria, Bacteroidetes, Spirochaetes, Chloroflexi, Planctomycetes a Synergistes [56-61]. Archaea represents approximately $5-6 \%$ of the total microbial population in anaerobic fermenters. Most studies examining the presence of archaea in anaerobic degradation and methanogenesis mention a representative of the Euryarchaeota phylum. Furthermore, their results point to the fact that the most abundant microorganisms from the Euryarchaeota phylum in anaerobic reactors are closely related to the genus Methanothrix $[55,60,62,63]$. Representatives of the acetoclastic order Methanosarcinales, especially Methanosarcinaceae and less often Methanosaetaceae, are also often detected in anaerobic reactors [64-68]. Moreover, genera of the order Methanomicrobiales, such as Methanoculleus sp. and Methanospirillum sp., can be found during anaerobic wastewater treatment. Species isolated from anaerobic biotechnology are, for example, Methanospirillum hungatei, Methanoculleus bourgensis or Methanolinea tarda [69-71]. Under thermophilic conditions, the diversity of microorganisms is not so large. Methanobacteriales is becoming the dominant order [72], especially the genus Methanobacterium. This hydrogenotrophic genus includes species adapted to higher temperatures and isolation of its species from anaerobic sludges is common. Examples are Methanobacterium subterraneum, Methanothermobacter thermoautotrophicus, and Methanothermobacter wolfei [73-76]. Within the order Methanosarcinales, mesophilic species are replaced by thermophilic species $[77,78]$.

\subsection{Inhibitors and Methanogenic Activity}

Anaerobic digestion is particularly susceptible to the strict control of the environmental conditions, as the process requires an interaction between fermentative and methanogenic organisms [11]. Anaerobic biodegradability and methanogenic toxicity are strongly dependent on wastewater characteristics. Toxic substances present in wastewater can interfere with the metabolism of readily biodegradable substrates [79]. There is a lot of industrial wastewaters amenable to anaerobic biotechnology. Nevertheless, these effluents may have properties that can cause process inhibition. The main influencing properties are temperature, $\mathrm{pH}$, alkalinity, volatile acids concentration, redox potential, salinity, macro and micro nutrient deficiency, presence of specific cations $\left(\mathrm{Ca}^{2+}, \mathrm{Na}^{+}, \mathrm{K}^{+}, \mathrm{Mg}^{2+}\right.$, $\mathrm{NH}_{4}{ }^{+}$), hydrogen, sulphide, heavy metals, bleaching and dyeing agents, antibiotics, etc. [12,45,48,51]. The temperature is influencing the enzymatic reaction rates and substrate diffusion rates. Changes in $\mathrm{pH}$, alkalinity and volatile acid concentration may affect enzyme activity and increase the toxicity of 
a number of compounds [11]. Ammonia inhibition on methanogenic process is poorly understood. The research shows that high ammonia concentration would result in a shift in methanogenic acetate utilization from direct acetate cleavage toward syntrophic acetate oxidation [80]. Change in the intracellular $\mathrm{pH}$, increase of maintenance energy requirement, and inhibition of a specific enzyme reaction was also reported [81]. The analysis of natural ${ }^{13} \mathrm{C}$ abundances of $\mathrm{CH}_{4}$ and $\mathrm{CO}_{2}$ indicated that the acetoclastic methanogenesis was more sensitive than hydrogenotrophic methanogenesis [82]. The toxic effect of heavy metals is attributed to the disruption of enzyme function and structure by binding the metals with thiol and other groups on protein molecules or by replacing naturally occurring metals in enzyme prosthetic groups [81,83]. Cations $\mathrm{Ca}^{2+}, \mathrm{Na}^{+}, \mathrm{K}^{+}, \mathrm{Mg}^{2+}$ were found to be antagonistic to ammonia inhibition [84]. Sulphide causes native protein denaturation through the formation of sulfide and disulfide cross-links between polypeptide chains [12]. High-salinity wastewater causes bacterial cells to dehydrate due to osmotic pressure [12]. The relative toxicity of chlorophenols has been investigated by many researchers. The results show that chlorophenols with greater hydrophobicity accumulate more efficiently in membranes, causing a greater disturbance to the membrane structure [85]. Halogenated aliphatics are strong inhibitors of methanogenesis. Brominated compounds were more inhibitory to methanogens than their chlorinated analogs [86]. Long-chain fatty acids (LCFAs) show acute toxicity by adsorption onto the cell wall/membrane and/or interference with the transport or protective function [87]. Lignin derivatives with aldehyde groups or apolar substituents are highly toxic to methanogens [81]. Effluent containing chlorine-bleaching agents, surfactants and antibiotics is problematic for anaerobic wastewater treatment due to its high toxicity for methanogenic archaea. Many of the above-described principles causing inhibiton thus decrease in treatment efficiency [11,81].

\subsection{Slaughterhouse Wastewater}

In the slaughter processes according to Massé and Masse (2000) [88], there is 90 to $140 \mathrm{~L}$ of produced wastewater per slaughtered pig. However, in terms of the consumption of "clean" water, these values are up to $30 \%$ higher since there is some water loss between the inflow and outflow from the slaughterhouse. In this case, however, these are still relatively low values due to efficient water management. Slaughterhouses, including the processing of meat into meat products, use about seven to eleven times more "clean" water per slaughtered pig [88]. However, wastewater volumes vary over time and on specific slaughterhouses and their facilities [13]. It can also be said that, in general, slaughter of poultry consumes many times more water than the slaughter of pigs or cows (Mittal, 2004). Slaughterhouse effluents may contain inedible residues such as skin, offal, blood, manure, fat, undigested stomach contents, and intestinal contents, etc. The effluent is accumulated in a retention tank, which is usually located under the slaughterhouse floor. Water is used here for many processes from hairlessing to cooling to rinsing tools. The composition of slaughterhouse wastewater depends mainly on the type of animal and the processes that take place in the slaughterhouse [13]. Wastewater from poultry slaughter may contain a certain amount of blood and offal, but after the separation of these residues, the content of the organic component is relatively small [89]. According to Massé and Masse (2000) [88], wastewater from pig slaughterhouses contains high concentrations of biodegradable organic substances and is very suitable for anaerobic treatment in terms of biochemical oxygen demand (BOD) values, amounts of nutrients and micronutrients. Generally, the wastewater of slaughterhouses has a high pollution load. The high lipid and protein content of slaughterhouse wastewater makes it a challenging material for anaerobic treatment. Lipids and protein hydrolysis may cause inhibition caused by volatile fatty acids (VFAs) and ammonia accumulation $[80,90]$. Uneven wastewater inflow and organic load during the day can also cause problems during anaerobic digestion of these wastewater type.

Relatively permanent representatives of methanogenic archaea in anaerobic bioreactors are representatives of the genus Methanothrix [91-93]. In laboratory or pilot anaerobic reactors, which were filled with various substrates such as breeding wastewater, slaughterhouse wastewater or a 
mixture of different residues from meat processing and livestock farming, representatives of the genus Methanothrix prevaled in methanogenic community in bioreactors [43,63,92,94-96]. In addition to the genus Methanothrix, similarities to effluents from alcoholic beverage and food processing can be found primarily in the presence of the genera Methanosarcina, Methanospirillum, Methanobacterium and Methanoculleus across these reactors [43,63,92,94-96]. In a study by Senés-Guerrera et al. (2019) [43], the percentage of Methanoculleus sp. increases with increasing bioreactor operation, while the proportion of Methanothrix sp. decreases. Methanoculleus sp. is also associated in this study with the period of the highest methane production in the bioreactor. These are species representatives of $M$. marisnigri and $M$. horonobensis. Representatives of M. marisnigri use molecular hydrogen and carbon dioxide, formate, and sometimes secondary alcohols to produce energy while producing methane. Their natural habitats are marine sediments or anaerobic bioreactors [97]. M. horonobensis also uses hydrogen and carbon dioxide or formate as starting materials for methane formation [98].

Studies of methanogenic communities arising in the reactor after a continuous inflow of pig and slurry effluent highlight the presence of representatives of the genera Methanocorpusculum and Methanobrevibacter $[63,91,92]$. These authors relate members of the Methanogenium genus to samples from anaerobic reactors that process wastewater from pig farming. Senés-Guerrero et al. (2019) [43] in their study samples from the laboratory bioreactor filled with biomass, which is to represent residues from beef breeding and processing. The composition of the methanogenic microbial community in this case differed from all those mentioned. The most prevalent were two genera, Methanoregula sp. and Methanofollis sp. Han et al. (2019) [92] also by studying samples from the reactors directly at the place of pig breeding, found genera representatives who were not mentioned in the previously mentioned studies, the genera Methanimicrococcus and Methanosphaera representatives.

\subsection{Brewery Wastewater}

The average water consumption to produce one liter of beer is five to six liters, but the consumption can increase up to eleven liters of water per liter of beer. Most of the water is consumed in beer production processes and approximately one third of the water is consumed for washing equipment and premises [99]. Brewery high-strength effluents with a temperature $>35^{\circ} \mathrm{C}$ are generally well biodegradable. Brewery wastewater has a favorable COD/BOD ratio. Organic compounds present in brewery wastewater consist of sugars, soluble starch, ethanol, volatile fatty acids, etc. therefore represent a suitable substrate for anaerobic digestion [22]. However, the composition of wastewater can vary quite a bit depending on the part of the day or even the season. This water will vary significantly over time in temperature, $\mathrm{pH}$, insoluble matter content, and organic and inorganic content [100]. Fluctuations in $\mathrm{pH}$ values in brewery wastewater can be somewhat problematic to an anaerobic treatment. Wastewater as a result of various brewing processes acquires both acidic and basic values (Table 4). For final neutralization before biological treatment processes, all these waters are accumulated in a buffer tank, where they are subsequently treated with hydrochloric acid, sodium hydroxide or phosphate buffers [101]. The use of chemical $\mathrm{pH}$ equalization is another step that increases the cost of wastewater treatment. An alternative to such methods may be gases generated during anaerobic treatment. Carbon dioxide has already been used to neutralize alkaline wastewater from the brewery in the study but is not yet used as an acidifying agent in buffer tanks before anaerobic treatment [22]. Most common methanogens present in the reactors processing brewery wastewater belonged to the orders Methanobacteriales, Methanococcales and Methanomicrobiales. Methanothrix sp. (formerly Methanosaeta), acetoclastic methanogen was found to be the dominant genus in reactor treating brewery wastewater [55,102-107]. This could be explained by the favorable concentration of acetate in brewery wastewater [27]. Other methanogens found in the reactors processing brewery wastewater were Methanococcus sp., Methanosarcina sp. and Methanospirillum sp. also present. 


\subsection{Distilleries Wastewater}

Alcohol distilleries generate large volumes of high-strength wastewater. Its characteristics are highly variable and depends on the input material used and various aspects of the production process. Generally, the distillery wastewater is characterized by its low $\mathrm{pH}$, dark brown color, high temperature $50-100{ }^{\circ} \mathrm{C}$, low dissolved oxygen content, high BOD and COD content (Table 4). Distillery effluent also contains significant amount of phenols, chlorides, sulphates, nitrates, phosphates, heavy metals and organic compounds, such as polysaccharides, reduced sugars, lignin, proteins, waxes, melanoidin, etc. [23]. The dark brown color of the effluent is mainly caused by melanoidin formation during a non-enzymatic browning reaction called Maillard reaction [108]. The high protein content of distillery wastewater can lead to a high concentration of ammonia released during the anaerobic digestion process. This can lead to process inhibition, biogas yield reduction, malodor and low methane content [80]. Heavy metals present in wastewater can be stimulatory, inhibitory, or toxic for microorganisms during anaerobic digestion, depending on their concentrations [109]. Melanoidins are highly recalcitrant and have antioxidant properties which make them toxic to many microorganisms. During the thermophilic anaerobic co-digestion of Sherry-wine, distillery wastewater increase in the organic load caused a reduction of the Methanosarcina sp. and an increase in Methanothrix sp., while, in the case of thermophilic reactor, it favored the increasing of Methanothermobacter sp. and Methanoculleus sp. [110]. In thermophilic anaerobic hybrid reactors treating energy cane stillage, Methanothermobacter was abundant. Methanogenic genera correlated to the stabilization and perturbation stages were methanogenic Methanothermobacter and Methanosarcina [111]. Most dominant in microbial community in anaerobic digesters processing wheat-based fuel ethanol waste streams were genera Methanothermobacter marburgensis and Methanosarcina barkeri [112].

\subsection{Pulp and Paper Industry Wastewater}

The pulp and paper industry supplies an essential product-paper-to over 7 billion people worldwide. The pulp and paper industry generates specific wastewater that contains compounds from pulp production and chemicals added during the processing. The pulp and paper industry effluent contains high values of BOD, COD and hundreds of chlorinated chemicals termed as absorbable organic halides (AOX). Cellulose, hemicellulose and lignin are the main components of wood and therefore have a decisive influence on the composition of wastewater from this production process. Lignin is degraded to a variety of high-, medium-, and low-molecular-weight chlorinated and non-chlorinated fractions. Lignin and its derivatives are highly toxic compounds responsible for the high BOD and COD values of effluents as well as the dark brown color of pulp effluents formed during pulping [113]. Lignocellulosic materials present in this type of wastewater can slow down the hydrolysis step of the anaerobic digestion process. The lignin is converted to alkaline-soluble compounds by treatment with bleaching agents (chlorine, chlorine dioxide and hypochlorite), and then washed out with sodium hydroxide. During this process, a number of highly toxic compounds, such as chlorinated lignosulfonic acids, chlorinated resin acids, chlorinated phenols, guaiacols, catechols, benzaldehydes, vanillins, syringo-vanillins, and chloropropioguaiacols, are formed [114]. Bleaching agents can cause anaerobic process instability due to the presence of toxic substances that affect methanogens. Bleachery effluents mainly contain degradation products of lignin. Smaller amount of polysaccharide and wood-extractive degradation products are generated. Methanol and various hemicelluloses are dominant organic compounds (over $90 \%$ ) in bleaching liquors. A vast variety of organochlorines are created. Non-chlorinated compounds present in wastewater are resin acids, fatty acids, sterols, diterpene alcohols, and tannins [115]. The toxicity of tannins to methanogens, which depends on the degree of polymerization, has been reported. Effluent dissolved compounds from alkaline peroxide bleaching (5-20 kg/t pulp) consist of carbohydrates (60\%), acetic acid, formic acid and methanol $(40 \%)$ [116]. Very important is the anaerobic reactor configuration. Operational and environmental conditions such as the reactors' operating temperature and $\mathrm{pH}$ play a crucial role in relation to HRT. Microbial communities of the sludge samples from anaerobic bioreactors operated with wastewater 
from pulp and paper industry were investigated in Thailand [117]. Predominant methanogenic archaea are in this process hydrogenotrophic methanogens Methanobacterium sp. and acetoclastic Methanothrix sp. These archaea in anaerobic bioreactors coexist with sulfate-reducing bacteria (SRB). For SRB, sulfate or sulfite in a bioreactor environment is very important. They use those compounds in the anaerobic oxidation process for the formation of hydrogen sulfide. Hydrogen sulfide is a gas that can reduce the quality and quantity of produced biogas. In paper industry sulfates represent the principal wastewater component. Jantharadej [117] and Roest [118] have identified uncultured Desulfobulbus sp., Syntrophobacter sp. and Desulfovibrio sp. In bioreactor sludge samples. SRB are a polyphyletic group of bacteria which are physiologically versatile. They are playing not only the role of sulfate reducers, but they have also suitable enzymes for the decomposition of propionate and butyrate as the key processes during organic matter degradation and methane production.

SRB can probably combine the properties of syntrophic growth and sulfate reduction. These bacteria have butyrate oxidizing capabilities in syntrophy with methanogenic archaea [118].

We can conclude that the wastewater originating from the pulp and paper industry is characterized by a typical microbial composition. The members of the family Cellulomonadaceae are irreplaceable in hydrolyzing cellulose and carbohydrates. A very important role also involves propionate producers, for example, members of the genus Propionibacterium. On the metabolic products of the previous groups follow short-chain fatty acid oxidizers and sulfate reducers which are very common in paper industry wastewaters. Together with methanogenic archaea members, Methanobacterium sp. and Methanothrix sp. represent an efficient consortium of microorganisms with the aim of high methane production.

4.6. Food and Drink Processing (Dairy Products, Vegetable Oil, Fruits and Vegetables, Canneries, Juice Making, etc.) Wastewater

\subsubsection{Dairy Industry Wastewater}

The dairy industry generates approximately $0.5-2 \mathrm{~m}^{3}$ of effluent per $\mathrm{m}^{3}$ of processed milk [119]. In the dairy industry, wastewater quantity and quality are very problematic because of great fluctuation. Typically, the dairy industry wastewater has an elevated temperature $\left(30-40{ }^{\circ} \mathrm{C}\right)$ and large variations in $\mathrm{pH}$, total suspended solids (TSS), BOD, COD, total nitrogen (TN), total phosphorus (TP) and fat, oil and grease. Wastewater with the highest concentration of pollution is generated in terms of daily production at the end of the day during the washing and sanitizing of the equipment and treatment facilities. In terms of the seasonal production of milk and dairy products, wastewater changes mainly in the volumes and concentrations of organic pollution [20,21]. Major constituents of dairy wastewater are lactose, soluble proteins, lipids, mineral salts and detergents while low concentrations of some heavy metals have been reported [20]. As one of the main components in dairy wastewater, we can find milk fat (4-22\% of DM), proteins and hydrocarbons in various forms, which are associated with milk [20]. Lactose is also an important dairy industry wastewater component. Lactose is converted through the Emden-Meyerhof-Parnas pathway to an intermediate product (acetate, lactate, ethanol, and formate, propionate and valerate), of which acetate represents 70\% [120]. Proteins are hydrolyzed by extracellular proteases into peptides. Peptides are metabolized by peptidases to amino acids, which are degraded to end products (volatile acids, ammonia, $\mathrm{H}_{2}$ and $\mathrm{CO}_{2}$, and sulfur-containing compounds) [121]. Ammonia, known for its toxicity, can be a major problem during the anaerobic fermentation of dairy wastewater if generated in high concentrations [80]. Dairy wastewater is characterized by very low alkalinity; thus, volatile fatty acids could rapidly accumulate within the anaerobic digester and cause a drop in the $\mathrm{pH}$. Additionally, lack of sufficient buffering capacity could lead to failure in bioreactor operation, and low $\mathrm{pH}$ may inhibit methanogenic activity [41]. The high salinity of dairy wastewaters is associated with the addition of $\mathrm{NaCl}, \mathrm{KCl}$ and calcium salts during production process. Sodium toxicity is a common problem which inhibits the methane-producing consortia during the anaerobic treatment of dairy wastewater [122]. Dairy wastewater components, which are relatively readily biodegradable, cause the BOD of wastewater from the dairy industry to be quite high and are therefore also a suitable substrate for biological treatment. However, wastewater 
may contain other components, such as cleaning agents [19] causing inhibition. Most of the used chemicals $\left(\mathrm{NaOH}, \mathrm{HCl}, \mathrm{HNO}_{3}\right.$ and $\left.\mathrm{H}_{3} \mathrm{PO}_{4}\right)$ are very toxic to microorganisms. The cleaning solutions are usually high in temperature $60-80{ }^{\circ} \mathrm{C}$. Strong oxidants or bleaches $\left(\mathrm{NaOCl}\right.$ and $\left.\mathrm{ClO}_{2}\right)$ are applied for sanitizing installations. $\mathrm{NaOH}$, the main cleaning agent, causes the $\mathrm{pH}$ of dairy wastewater to often be around highly basic values [20]. Methanothrix sp. was found to be the predominant active methanogen throughout the trial at low-temperature anaerobic treatment of dairy wastewater [123]. During synthetic wastewater treatment, most abundant microbial taxa in the reactor belonged to the Methanobacteria and Methanomicrobia classes, which solely consisted of the hydrogenotrophic genus Methanobacterium and the acetoclastic genus Methanothrix [124]. Methanomicrobium, Methanobrevibacter, Methanocalculus, Methanosarcina, Methanothrix, Methanoculleus and Methanofollis genera were reported in reactor processing wastewater that originated from the dairy industry [120].

\subsubsection{Vegetable Oil Industry Wastewater}

Palm, soybean, olive, cottonseed, and sunflower oils are essential in human diet over the world. In 2019, the annual production of vegetable oils was 203.91 million metric tons. The most utilized vegetable oil is palm oil with $37 \%$ of the vegetable oil production [125]. The production of edible oil is associated with the generation of various wastes. Outside of organic solid wastes (seeds, husks) and inorganic residues a big amount of wastewater is generated. During the palm oil production, $0.5-0.75$ tons of palm oil mill effluent per one ton of fresh fruits is generated on average [126]. The olive oil mill wastewater represents 8 million tons generated annually worldwide [127]. On average, $1.2-1.8 \mathrm{~m}^{3}$ wastewater is generated per one ton of olives because of the oil extraction process. Wastewater generated in the vegetable oil industry is typical high in COD, BOD, TDS and TSS content. It is also common for this wastewater to be in high phosphate and sulfate content. Important is a high concentration of lipids, more than $100 \mathrm{mg} / \mathrm{L}$, and it is acidic in nature with a $\mathrm{pH}$ of approximately 4.5 . Lipid-containing material is rich in long-chain fatty acids (LCFAs), which are degraded anaerobically via the $\beta$-oxidation pathway to acetate and $\mathrm{H}_{2}$. Some publications reported an LCFA toxicity effect on methanogenic Archaea, caused by a not well described mechanism, probably by the surfactant effect of the LCFAs [128]. The amounts of cellulose, hemicellulose and lignin in palm oil mill effluent (POME) are $11 \%, 7 \%$ and $42 \%$, respectively [129]. In the oil industry, fluidized bed reactors, upflow anaerobic sludge blanket reactors and continuous stirred-tank reactors are widely used for the treatment of wastewater. The very-cost-effective anaerobic treatment method represents anaerobic ponds and lagoons [126]. Disadvantage of ponds and lagoons treatment is the high retention time of wastewater. Comparing aerobic and anaerobic treatment methods for oil wastewater treatment brings clear results. The anaerobic technology shows a higher removal efficiency and 20 times lower sludge formation [130]. Palm oil mill effluent can be very efficiently converted to methane, with a maximum methane yield of $33.2 \mathrm{CH}_{4} / \mathrm{t}$ POME [129]. In literature, we can find only little information about microorganisms involved in the POME methanization process. Miller (2015) [131] described a relatively high abundance of hydrogenotrophic methanogens from the Methanobacteriales order (Methanosphaera sp.). Macllroy et al. (2017) [132] mentioned the presence of hydrogenotrophic genera Methanobrevibacter and Methanothermobacter in mesophilic temperature and acetoclastic Methanothrix sp. and Methanosarcina sp. present only at $50{ }^{\circ} \mathrm{C}$ process temperature.

\subsubsection{Fruit and Vegetable Processing Industry Wastewater}

Water consumption in fruit and vegetable processing industries is high $\left(5-50 \mathrm{~m}^{3} / \mathrm{t}\right)$, and most of the process water became wastewater. Fruit and vegetable process plant wastewater typically contains discarded fruits and vegetables, soil particles, fruit and veg pulp and fibers, cleaning agents, blanching agents, salts and residues of pesticides. Wastewater streams are characterized by lower COD and BOD loads compared to other food sectors, including meat processing industries and olive oil processing plants [29]. Fruit and vegetable waste contains low cellulose content, and the C:N ratio of the wastes may accelerate ammonia release, resulting in the inhibition of methanogenesis in anaerobic reactors. The low 
$\mathrm{pH}$ of these wastewaters can cause inhibition of anaerobic digestion when dilution of wastewater is no applied. The accumulation of VFAs was also reported as a possible reason for process inhibition. Predominant methanogens genera during the anaerobic co-digestion of fruit and vegetable waste were Methanoculleus, Methanothrix and Methanosarcina [133]. During the operation of a lab-scale UASB reactor treating fruit and vegetable waste, the Methanothrix spp. was dominant. After acclimation, the percentages of hydrogenotrophic methanogens including Methanolinea, Methanospirillum and Methanobacterium genera obviously increased; however, acetoclastic methanogen Methanothrix sp. and methylotrophic methanogens Methanomethylovorans sp. and Methanomassiliicoccus sp. decreased in the study [134]. During the digestion of the syrup wastewater produced while canning fruit, Methanothrix spp. was dominant when the methane gas vigorously evolved. Other methanogens found during anaerobic digestion were Methanobacterium sp. and Methanosarcina sp. [135].

Large volumes of wastewater are also produced in citrus-processing industries. About 120 million tons of citrus fruits are produced annually in the world and $20 \%$ of citrus fruits are industrially processed [136]. There are two types of residues emerging during technological processing, peel with $50 \%$ of wet fruit mass and wastewater. The most citrus-processing wastewater arises during fruit washing and device cleaning. The physicochemical characteristics of this type of wastewater determines many constraints for its disposal. Wastewater is typically low $\mathrm{pH}$, low concentration of nutrients with a high content of organic compounds and essential oils. Commonly used wastewater treatment processes include aerated filter systems, aerobic granular sludge sequencing batch reactors or microfiltration membranes [137]. Anaerobic wastewater treatment in lagoons represents an economically acceptable solution. Wastewater is treated for a long time (months) in large volumes in lagoons. During this time, adaptation of degrading microorganisms occurs not only to high substance load but also to low $\mathrm{pH}$ values typical for this type of wastewater. Anaerobic lagoons do not require energy and show $90 \%$ removal capacity of organic loading. Anaerobic digestion of citrus-processing wastewater is not practiced due to the inhibitory effect of inhibiting compounds as limonen [138].

\subsection{Chemical Industry Wastewater}

The chemical industry produces a wide range of organic chemicals. The number of organic chemicals produced is increasing rapidly and the toxicity limits for the environment is far from being known for all the chemicals manufactured [34]. Chemical industrial wastewaters usually contain organic and inorganic contaminants in varying concentrations. Many materials used in the chemical industry are toxic, mutagenic, carcinogenic or simply almost non-biodegradable aromatic compounds [139]. Thus, it is very difficult to summarize general facts about the composition of chemical industry wastewater. Each company produces wastewaters possessing different types of contaminants under various operational parameters. The contamination of chemically polluted wastewaters depends mostly on the company production lines and formulations [34].

Phenol derivates are often found in the wastewaters from industry. Phenol is known as biocide and disinfectant, so it is often associated with being inhibitory to microorganisms. Fang et al. conducted an experiment to prove that phenol can be effectively degraded (97\%) at UASB reactor. The results of archaeal community analysis showed the presence of two hydrogenotrophic representants, Methanospirillum sp. and Methanobrevibacter sp., and one acetoclastic representant, Methanotrix sp. [140]. Muňoz et al. [141] found that Methanosarcinales (46.86\%) was the dominant archaea order in the UASB and Methanobacteriales (26.22\%) and Methanosarcinales (23.99\%) orders in the anaerobic membrane bioreactors (AnMBR). At the end of the experiment, Methanotrix sp. dominated in AnMBR. During glycerol containing wastewater anaerobic treatment, two main groups, Methanobacterium sp. and Methanosarcina sp., have been found [142]. Another study [143] reported that Methanosarcina, Methanosarcinales, and Methanobrevibacter were dominant genera during residual glycerol anaerobic digestion. In sulfate-rich chemical wastewater, the largest group of methanogens was Methanothrix sp., which accounted for $42.5 \%$ in the library. Among them, the species closely related to Methanothrix concilii (similarity $99 \%$, relative abundance $40.0 \%$ ) and Methanothrix harundinacea (similarity $99 \%$, relative abundance 
2.5\%) used acetate for growth and methane production as a carbon source. Methanobacterium sp. and Methanoregula sp. show the second and third largest relative abundance of the genera, respectively [144]. During acetone-butanol-ethanol wastewater treatment, Methanocorpusculum sp. and Methanoculleus sp. were found as dominant methanogens [145]. The ability of Methanotrix sp. for the degradation of acetone in enrichment culture was proved in this study [146]. During anaerobic solvent degradation in the low-temperature occurrence, Methanotrix sp. and Methanosarcina sp. were confirmed as the most abundant species [147]. In the UASB reactor for iso-prophyl alcohol (2-propanol) wastewater treatment, Methanospirillum sp. (61\%) was dominated. Clones from the genera Methanolinea sp. (36\%) and Methanomicrobium sp. (3\%) were also detected [148].

\section{Conclusions}

Anaerobic wastewater treatment is highlighted in many sources as a very efficient and ecological alternative to aerobic technologies. Today, this technology is already used in many industries, especially in the food industry. Technically, it is a relatively simple technology. However, anaerobic sludge, which is essential for anaerobic decomposition, remains a little-explored and complex part of the technology. Anaerobic digestion is the process in which macromolecules, such as polysaccharides, lipids, and proteins, are broken down by an anaerobic community of microorganisms into simple components from which the methanogenic archaea forms methane as a component of biogas. Representatives of the methanogenic communities of the Archaea domain then belong to the Euryarchaeota phylum (Table 7). Based on the literature review, it is possible to conclude at least that a relatively permanent part of the community of methanogenic archaea in anaerobic sludge, with a few exceptions, are genera Methanothrix and Methanosarcina, acetoclastic representatives of methanogens. The diversity of methanogens is reflected in the different growth conditions, temperature, $\mathrm{pH}$ and osmolarity. Most of the methanogens grow optimally around neutral $\mathrm{pH}$. Higher wastewater $\mathrm{pH}$ can be tolerated by halotolerant strains of methanogens. For example, in dairy wastewater, Methanocalculus sp. was reported as part of the methanogenic community. On the other hand, moderately acidic environments can be inhabited by methanogens as, for example, Methanoregula sp. Methanosarcina sp. and Methanococcus sp. Salt concentration may also be an important physiological parameter for methanogens. In high-salinity brewery, paper and dairy wastewater representants, Methanobacterium sp., Methanosarcina sp. and Methanothrix sp. can be found. We can prove the theories that Methanothrix sp. plays a key role in granulation and in the core of the granules' function as nucleation centers that initiate granule development. From Table 7, it is clear that hydrogenotrophic methanogens diversity richness is higher in most anaerobic bioreactors. 
Table 7. Methanogens prevailed in anaerobic bioreactors treating industrial wastewater.

\begin{tabular}{|c|c|c|c|c|c|c|c|c|c|}
\hline \multirow{2}{*}{$\begin{array}{c}\text { Genera of } \\
\text { Methanogens }\end{array}$} & \multirow{2}{*}{$\begin{array}{c}\text { Methanogenic } \\
\text { Metabolic Pathway }\end{array}$} & \multicolumn{8}{|c|}{ Industry } \\
\hline & & Slaughterhause & Brewery & Distillery & Paper & Dairy & Vegetable Oil & Fruit and Vegetable & Chemical \\
\hline Methanothrix & $\begin{array}{l}\text { acetoclastic } \\
\text { acetoclastic }\end{array}$ & $\bullet$ & $\bullet$ & $\bullet$ & $\bullet$ & $\bullet$ & $\bullet$ & $\bullet$ & $\bullet$ \\
\hline Methanosarcina & $\begin{array}{l}\text { hydrogenotrophic } \\
\text { methylotrophic }\end{array}$ & $\bullet$ & $\bullet$ & $\bullet$ & & $\bullet$ & $\bullet$ & $\bullet$ & $\bullet$ \\
\hline Methanomicrobium & hydrogenotrophic & & & & & - & & & - \\
\hline Methanobrevibacter & hydrogenotrophic & $\bullet$ & & & & $\bullet$ & & & $\bullet$ \\
\hline Methanocalculus & hydrogenotrophic & & & & & $\bullet$ & & & \\
\hline Methanoculleus & hydrogenotrophic & - & & - & & - & & - & - \\
\hline Methanofollis & hydrogenotrophic & - & & & & - & & & \\
\hline Methanobacterium & hydrogenotrophic & $\bullet$ & & & - & - & & - & - \\
\hline Methanoregula & hydrogenotrophic & - & & & & & & & $\bullet$ \\
\hline Methanococcus & hydrogenotrophic & & $\bullet$ & & & & & & \\
\hline Methanospirillum & hydrogenotrophic & - & - & & & & & - & - \\
\hline Methanocorpuscullum & hydrogenotrophic & - & & & & & & & $\bullet$ \\
\hline Methanogenium & hydrogenotrophic & - & & & & & & & \\
\hline Methanimicrococcus & methylotrophic & $\bullet$ & & & & & & & \\
\hline Methanosphaera & hydrogenotrophic & - & & & & & $\bullet$ & & \\
\hline Methanothermobacter & hydrogenotrophic & & & - & & & & & \\
\hline Methanolinea & hydrogenotrophic & & & & & & & $\bullet$ & $\bullet$ \\
\hline Methanomethylovorans & methylotrophic & & & & & & & $\bullet$ & \\
\hline Methanomassiliicoccus & methanol $+\mathrm{H}_{2}$ & & & & & & & $\bullet$ & \\
\hline
\end{tabular}


Author Contributions: The authors participated in the preparation of the article as follows: conceptualization, M.V., A.K. and T.V.; formal analysis, M.V., A.K., T.V., N.H. and I.K.; writing-original draft preparation, M.V., A.K., T.V., and N.H.; writing-review and editing M.V., A.K., T.V. and I.K.; visualization T.V.; supervision, M.V., T.V. and I.K. All authors have read and agreed to the published version of the manuscript.

Funding: This research was funded by Masaryk university internal grant MUNI/A/0947/2019.

Conflicts of Interest: The authors declare no conflict of interest.

\section{References}

1. Mourelatou, A.; European Environment Agency. Environmental Indicator Report 2018: In Support to the Monitoring of the Seventh Environment Action Programme; European Environment Agency: Copenhagen, Denmark, 2018; ISBN 978-92-9480-017-6.

2. Ritchie, H.; Roser, M. Water Use and Stress. Available online: https://ourworldindata.org/water-use-stress (accessed on 8 September 2020).

3. The State of the World's Land and Water Resources for Food and Agriculture: Managing Systems at Risk, 1st ed.; Earthscan: Abingdon, UK; New York, NY, USA, 2011; ISBN 978-1-84971-326-9.

4. Bal, A.S.; Dhagat, N.N. Upflow anaerobic sludge blanket reactor-A review. Indian J. Environ. Health 2001, 43, 1-82. [PubMed]

5. Macarie, H. Overview of the application of anaerobic treatment to chemical and petrochemical wastewaters. Water Sci. Technol. 2000, 42, 201-214. [CrossRef]

6. Cisneros, B.J. Safe Sanitation in Low Economic Development Areas. In Treatise on Water Science; Elsevier: Amsterdam, The Netherlands, 2011; pp. 147-200. ISBN 978-0-444-53199-5.

7. Singh, K.S.; Harada, H.; Viraraghavan, T. Low-strength wastewater treatment by a UASB reactor. Bioresour. Technol. 1996, 55, 187-194. [CrossRef]

8. Ma, B.; Peng, Y.; Zhang, S.; Wang, J.; Gan, Y.; Chang, J.; Wang, S.; Wang, S.; Zhu, G. Performance of anammox UASB reactor treating low strength wastewater under moderate and low temperatures. Bioresour. Technol. 2013, 129, 606-611. [CrossRef]

9. Lay, C.-H.; Vo, T.-P.; Lin, P.-Y.; Abdul, P.M.; Liu, C.-M.; Lin, C.-Y. Anaerobic hydrogen and methane production from low-strength beverage wastewater. Int. J. Hydrog. Energy 2019, 44, 14351-14361. [CrossRef]

10. Muralikrishna, I.V.; Manickam, V. Industrial Wastewater Treatment Technologies, Recycling, and Reuse. In Environmental Management; Elsevier: Amsterdam, The Netherlands, 2017; pp. 295-336. ISBN 978-0-12-811989-1.

11. Gerardi, M.H. The Microbiology of Anaerobic Digesters; Wastewater Microbiology Series; Wiley-Interscience: Hoboken, NJ, USA, 2003; ISBN 978-0-471-20693-4.

12. Speece, R.E. Anaerobic biotechnology for industrial wastewater treatment. Environ. Sci. Technol. 1983, 17, 416A-427A. [CrossRef]

13. Wu, P.F.; Mittal, G. Characterization of provincially inspected slaughterhouse wastewater in Ontario, Canada. Can. Biosyst. Eng. 2012, 54, 6.9-6.18. [CrossRef]

14. Caixeta, C.E.T.; Cammarota, M.C.; Xavier, A.M.F. Slaughterhouse wastewater treatment: Evaluation of a new three-phase separation system in a UASB reactor. Bioresour. Technol. 2002, 81, 61-69. [CrossRef]

15. Del Nery, V.; Damianovic, M.H.Z.; Moura, R.B.; Pozzi, E.; Pires, E.C.; Foresti, E. Poultry slaughterhouse wastewater treatment plant for high quality effluent. Water Sci. Technol. 2016, 73, 309-316. [CrossRef]

16. Gomes, A.J.G.; Atambo, D.O.; Das, K.K.; Cocke, D.L.; Das, K.P. Electrochemical remediation of chicken processing plant wastewater. J. Environ. Chem. Eng. 2018, 6, 6028-6036. [CrossRef]

17. Erden, G.; Buyukkamaci, N.; Filibeli, A. Effect of low frequency ultrasound on anaerobic biodegradability of meat processing effluent. Desalination 2010, 259, 223-227. [CrossRef]

18. Choi, Y.S.; Hong, S.W.; Kim, S.J.; Chung, I.H. Development of a biological process for livestock wastewater treatment using a technique for predominant outgrowth of Bacillus species. Water Sci. Technol. 2002, 45, 71-78. [CrossRef] [PubMed]

19. Monroy, O.H.F.; Vázquez, M.; Derramadero, J.C.; Guyot, J.P. Anaerobic-aerobic treatment of cheese wastewater with national technology in Mexico: The case of "El Sauz". Water Sci. Technol. 1995, 32, 149-156. [CrossRef]

20. Kasapgil, B.; Anderson, G.K.; Ince, O. An Investigation into the Pre-Treatment of Dairy Wastewater Prior to Aerobic Biological Treatment. Water Sci. Technol. 1994, 29, 205-212. [CrossRef] 
21. Ozturk, I.; Eroglu, V.; Ubay, G.; Demir, I. Hybrid upflow anaerobic sludge blanket reactor (HUASBR) treatment of dairy effluents. Water Sci. Technol. 1993, 28, 77-85. [CrossRef]

22. Rao, A.G.; Reddy, T.S.K.; Prakash, S.S.; Vanajakshi, J.; Joseph, J.; Sarma, P.N. pH regulation of alkaline wastewater with carbon dioxide: A case study of treatment of brewery wastewater in UASB reactor coupled with absorber. Bioresour. Technol. 2007, 98, 2131-2136. [CrossRef]

23. Sunil Kumar, G.; Gupta, S.K.; Singh, G. Biodegradation of distillery spent wash in anaerobic hybrid reactor. Water Res. 2007, 41, 721-730. [CrossRef]

24. Kharayat, Y. Distillery wastewater: Bioremediation approaches. J. Integr. Environ. Sci. 2012, 9, 69-91. [CrossRef]

25. Won, S.G.; Baldwin, S.A.; Lau, A.K.; Rezadehbashi, M. Optimal operational conditions for biohydrogen production from sugar refinery wastewater in an ASBR. Int. J. Hydrog. Energy 2013, 38, 13895-13906. [CrossRef]

26. Velasquez-Orta, S.B.; Head, I.M.; Curtis, T.P.; Scott, K. Factors affecting current production in microbial fuel cells using different industrial wastewaters. Bioresour. Technol. 2011, 102, 5105-5112. [CrossRef]

27. Eskelinen, K.; Särkkä, H.; Kurniawan, T.A.; Sillanpää, M.E.T. Removal of recalcitrant contaminants from bleaching effluents in pulp and paper mills using ultrasonic irradiation and Fenton-like oxidation, electrochemical treatment, and/or chemical precipitation: A comparative study. Desalination 2010, 255, 179-187. [CrossRef]

28. Habets, L.H.A.; De Vegt, A.L. Anaerobic treatment of bleached TMP and CTMP effluent in the biopaq UASB system. Water Sci. Technol. 1991, 24, 331-345. [CrossRef]

29. Valta, K.; Damala, P.; Panaretou, V.; Orli, E.; Moustakas, K.; Loizidou, M. Review and Assessment of Waste and Wastewater Treatment from Fruits and Vegetables Processing Industries in Greece. Waste Biomass Valorization 2017, 8, 1629-1648. [CrossRef]

30. Ma, Z.; Lei, T.; Ji, X.; Gao, X.; Gao, C. Submerged membrane bioreactor for vegetable oil wastewater treatment. Chem. Eng. Technol. 2015, 38, 101-109. [CrossRef]

31. Galliou, F.; Markakis, N.; Fountoulakis, M.S.; Nikolaidis, N.; Manios, T. Production of organic fertilizer from olive mill wastewater by combining solar greenhouse drying and composting. Waste Manag. 2018, 75, 305-311. [CrossRef]

32. Kalat, D.G.; Yüceer, A. Anaerobic mesophilic and thermophilic treatability of vegetable oil refining wastewater. Process Saf. Environ. Prot. 2017, 109, 151-157. [CrossRef]

33. Mohamed, A.A.H.; Al Shariff, S.M.; Ouf, S.A.; Benghanem, M. Atmospheric pressure plasma jet for bacterial decontamination and property improvement of fruit and vegetable processing wastewater. J. Phys. D Appl. Phys. 2016, 49. [CrossRef]

34. Jørgensen, S.E. (Ed.) Chapter 21 Manufacture of Organic Chemicals. In Industrial Waste Water Management; Studies in Environmental Science; Elsevier: Amsterdam, The Netherlands, 1979; Volume 5, pp. $273-282$.

35. Tchobanoglous, G.; Burton, F.L.; Stensel, H.D.; Metcalf, E. (Eds.) Wastewater Engineering: Treatment and Reuse, 4th ed.; McGraw-Hill Series in Civil and Environmental Engineering; McGraw-Hill: Boston, MA, USA, 2003; ISBN 978-0-07-041878-3.

36. van Lier, J.B.; Mahmoud, N.A.; Zeeman, G. Anaerobic Wastewater Treatment. In Biological Wastewater Treatment: Principles, Modelling and Design; IWA Publishing: London, UK, 2008; pp. 415-457. ISBN 978-1-84339-188-3.

37. Riffat, R.; Sajjad, M.W.; Dararat, S. Anaerobic processes. Water Environ. Res. 1998, 70, 518-540. [CrossRef]

38. Dionisi, D. Biological Wastewater Treatment Processes: Mass and Heat Balances; CRC Press, Taylor \& Francis Group: Boca Raton, FL, USA, 2017; ISBN 978-1-4822-2926-4.

39. Tchobanoglous, G.; Burton, F.L.; Metcalf, L.; Eddy, H.P. (Eds.) Wastewater Engineering: Treatment, Disposal, and Reuse, 3rd ed.; McGraw-Hill Series in Water Resources and Environmental Engineering; McGraw-Hill: New York, NY, USA, 1991; ISBN 978-0-07-041690-1.

40. Young, J.C.; McCarty, P.L. The anaerobic filter for waste treatment. J. Water Pollut. Control Fed. 1969, 41, R160-R173.

41. Khanal, S.K.; Giri, B.; Nitayavardhana, S.; Gadhamshetty, V. 10-Anaerobic Bioreactors/Digesters: Design and Development. In Current Developments in Biotechnology and Bioengineering; Lee, D.-J., Jegatheesan, V., Ngo, H.H., Hallenbeck, P.C., Pandey, A., Eds.; Elsevier: Amsterdam, The Netherlands, 2017; pp. 261-279. ISBN 978-0-444-63665-2. 
42. Cabezas, A.; de Araujo, J.C.; Callejas, C.; Galès, A.; Hamelin, J.; Marone, A.; Sousa, D.Z.; Trably, E.; Etchebehere, C. How to use molecular biology tools for the study of the anaerobic digestion process? Rev. Environ. Sci. Biotechnol. 2015, 14, 555-593. [CrossRef]

43. Senés-Guerrero, C.; Colón-Contreras, F.A.; Reynoso-Lobo, J.F.; Tinoco-Pérez, B.; Siller-Cepeda, J.H.; Pacheco, A. Biogas-producing microbial composition of an anaerobic digester and associated bovine residues. Microbiol. Open 2019, 8, e00854. [CrossRef] [PubMed]

44. Batstone, D.J.; Virdis, B. The role of anaerobic digestion in the emerging energy economy. Curr. Opin. Biotechnol. 2014, 27, 142-149. [CrossRef] [PubMed]

45. Holland, K.T.; Knapp, J.G.; Shoesmith, J.G. Anaerobic Bacteria. J. Basic Microbiol. 1990, 30, 379. [CrossRef]

46. Hungate, R.E. Hydrogen as an intermediate in the rumen fermentation. Arch. Mikrobiol. 1967, 59, $158-164$. [CrossRef] [PubMed]

47. Bryant, M.P. Microbial Methane Production-Theoretical Aspects2. J. Anim. Sci. 1979, 48, 193-201. [CrossRef]

48. Merlin, G.; Boileau, H. Anaerobic Digestion of Agricultural Waste: State of the Art and Future Trends; Nova Science Publishers, Inc.: New York, NY, USA, 2013.

49. Kushkevych, I.; Kováč, J.; Vítězová, M.; Vítěz, T.; Bartoš, M. The diversity of sulfate-reducing bacteria in the seven bioreactors. Arch. Microbiol. 2018, 200, 945-950. [CrossRef] [PubMed]

50. McCarty, P.L. The development of anaerobic treatment and its future. Water Sci. Technol. 2001, 44, 149-156. [CrossRef] [PubMed]

51. Van Lier, J.B.; van der Zee, F.P.; Frijters, C.T.M.J.; Ersahin, M.E. Celebrating 40 years anaerobic sludge bed reactors for industrial wastewater treatment. Rev. Environ. Sci. Biotechnol. 2015, 14, 681-702. [CrossRef]

52. Lettinga, G.; van der Geest, A.T.; Hobma, S.; Laan, J.V.D. Anaerobic treatment of methanolic wastes. Water Res. 1979, 13, 725-737. [CrossRef]

53. Van Lier, J.B. High-rate anaerobic wastewater treatment: Diversifying from end-of-the-pipe treatment to resource-oriented conversion techniques. Water Sci. Technol. 2008, 57, 1137-1148. [CrossRef]

54. Driessen, W.; Yspeert, P. Anaerobic treatment of low, medium and high strength effluent in the agro-industry. Water Sci. Technol. 1999, 40, 221-228. [CrossRef]

55. Díaz, E.E.; Stams, A.J.M.; Amils, R.; Sanz, J.L. Phenotypic Properties and Microbial Diversity of Methanogenic Granules from a Full-Scale Upflow Anaerobic Sludge Bed Reactor Treating Brewery Wastewater. Appl. Environ. Microbiol. 2006, 72, 4942-4949. [CrossRef] [PubMed]

56. Godon, J.J.; Zumstein, E.; Dabert, P.; Habouzit, F.; Moletta, R. Molecular microbial diversity of an anaerobic digestor as determined by small-subunit rDNA sequence analysis. Appl. Environ. Microbiol. 1997, 63, 2802-2813. [CrossRef] [PubMed]

57. Sekiguchi, Y.; Kamagata, Y.; Syutsubo, K.; Ohashi, A.; Harada, H.; Nakamura, K. Phylogenetic diversity of mesophilic and thermophilic granular sludges determined by $16 \mathrm{~S}$ rRNA gene analysis. Microbiology 1998, 144, 2655-2665. [CrossRef]

58. Keyser, M.; Britz, T.J.; Witthuhn, R.C. Fingerprinting and Identification of Bacteria Present in UASB Granules Used to Treat Winery, Brewery, Distillery or Peach-lye Canning Wastewater. S. Afr. J. Enol. Vitic. 2007, 28, 69-79. [CrossRef]

59. Fernández, N.; Díaz, E.E.; Amils, R.; Sanz, J.L. Analysis of Microbial Community during Biofilm Development in an Anaerobic Wastewater Treatment Reactor. Microb. Ecol. 2008, 56, 121-132. [CrossRef]

60. Narihiro, T.; Terada, T.; Kikuchi, K.; Iguchi, A.; Ikeda, M.; Yamauchi, T.; Shiraishi, K.; Kamagata, Y.; Nakamura, K.; Sekiguchi, Y. Comparative analysis of bacterial and archaeal communities in methanogenic sludge granules from upflow anaerobic sludge blanket reactors treating various food-processing, high-strength organic wastewaters. Microbes Environ. 2009, 24, 88-96. [CrossRef]

61. Peptidolytic Microbial Community of Methanogenic Reactors from Two Modified UASBs of Brewery Industries. Available online: https:/www.scielo.br/scielo.php?script=sci_arttext\&pid=S151783822010000300022\&lng=en\&nrm=iso\&tlng=en (accessed on 22 October 2020).

62. Zhang, L.; Ban, Q.; Li, J.; Wan, C. Functional bacterial and archaeal dynamics dictated by pH stress during sugar refinery wastewater in a UASB. Bioresour. Technol. 2019, 288, 121464. [CrossRef]

63. Leclerc, M.; Delgènes, J.P.; Godon, J.J. Diversity of the archaeal community in 44 anaerobic digesters as determined by single strand conformation polymorphism analysis and 16S rDNA sequencing. Environ. Microb. 2004, 6, 809-819. [CrossRef] 
64. Guo, J.; Peng, Y.; Ni, B.-J.; Han, X.; Fan, L.; Yuan, Z. Dissecting microbial community structure and methane-producing pathways of a full-scale anaerobic reactor digesting activated sludge from wastewater treatment by metagenomic sequencing. Microb. Cell Fact. 2015, 14, 33. [CrossRef]

65. Gao, J.; Liu, G.; Li, H.; Xu, L.; Du, L.; Yang, B. Predictive functional profiling using marker gene sequences and community diversity analyses of microbes in full-scale anaerobic sludge digesters. Bioprocess Biosyst. Eng. 2016, 39, 1115-1127. [CrossRef] [PubMed]

66. Kim, J.; Kim, W.; Lee, C. Absolute dominance of hydrogenotrophic methanogens in full-scale anaerobic sewage sludge digesters. J. Environ. Sci. (China) 2013, 25, 2272-2280. [CrossRef]

67. Vítěz, T.; Novák, D.; Lochman, J.; Vítězová, M. Methanogens Diversity during Anaerobic Sewage Sludge Stabilization and the Effect of Temperature. Processes 2020, 8, 822. [CrossRef]

68. Struk, M.; Vítězová, M.; Vítěz, T.; Bartoš, M.; Kushkevych, I. Modřice Plant Anaerobic Digester: Microbial Distribution and Biogas Production. Water Air Soil Pollut. 2019, 230, 240. [CrossRef]

69. Ferry, J.G.; Smith, P.H.; Wolfe, R.S. Methanospirillum, a New Genus of Methanogenic Bacteria, and Characterization of Methanospirillum hungatii sp.nov. Int. J. Syst. Bacteriol. 1974, 24, 465-469. [CrossRef]

70. Maus, I.; Wibberg, D.; Stantscheff, R.; Eikmeyer, F.-G.; Seffner, A.; Boelter, J.; Szczepanowski, R.; Blom, J.; Jaenicke, S.; Konig, H.; et al. Complete Genome Sequence of the Hydrogenotrophic, Methanogenic Archaeon Methanoculleus bourgensis Strain MS2T, Isolated from a Sewage Sludge Digester. J. Bacteriol. 2012, 194, 5487-5488. [CrossRef]

71. Imachi, H.; Sakai, S.; Sekiguchi, Y.; Hanada, S.; Kamagata, Y.; Ohashi, A.; Harada, H. Methanolinea tarda gen. nov., sp. nov., a methane-producing archaeon isolated from a methanogenic digester sludge. Int. J. Syst. Evol. Microbiol. 2008, 58, 294-301. [CrossRef]

72. Sun, W.; Yu, G.; Louie, T.; Liu, T.; Zhu, C.; Xue, G.; Gao, P. From mesophilic to thermophilic digestion: The transitions of anaerobic bacterial, archaeal, and fungal community structures in sludge and manure samples. Appl. Microbiol. Biotechnol. 2015, 99, 10271-10282. [CrossRef]

73. Kotelnikova, S.; Macario, A.J.L.; Pedersen, K. Methanobacterium subterraneum sp. nov., a new alkaliphilic, eurythermic and halotolerant methanogen isolated from deep granitic groundwater. Int. J. Syst. Bacteriol. 1998, 48, 357-367. [CrossRef]

74. Blotevogel, K.-H.; Fischer, U.; Mocha, M.; Jannsen, S. Methanobacterium thermoalcaliphilum spec. nov., a new moderately alkaliphilic and thermophilic autotrophic methanogen. Arch. Microbiol. 1985, 142, $211-217$. [CrossRef]

75. Winter, J.; Lerp, C.; Zabel, H.-P.; Wildenauer, F.X.; König, H.; Schindler, F. Methanobacterium wolfei, sp. nov., a New Tungsten-Requiring, Thermophilic, Autotrophic Methanogen. Syst. Appl. Microbiol. 1984, 5, 457-466. [CrossRef]

76. Zeikus, J.G.; Wolfe, R.S. Methanobacterium thermoautotrophicus sp. n., an anaerobic, autotrophic, extreme thermophile. J. Bacteriol. 1972, 109, 707-715. [CrossRef] [PubMed]

77. Levén, L.; Eriksson, A.R.B.; Schnürer, A. Effect of process temperature on bacterial and archaeal communities in two methanogenic bioreactors treating organic household waste: Temperature effects on microbial communities in bioreactors. FEMS Microbiol. Ecol. 2007, 59, 683-693. [CrossRef] [PubMed]

78. Weiss, A.; Jérôme, V.; Freitag, R.; Mayer, H.K. Diversity of the resident microbiota in a thermophilic municipal biogas plant. Appl. Microbiol. Biotechnol. 2008, 81, 163. [CrossRef]

79. Lettinga, G.; van Velsen, A.F.M.; Hobma, S.W.; de Zeeuw, W.; Klapwijk, A. Use of the upflow sludge blanket (USB) reactor concept for biological wastewater treatment, especially for anaerobic treatment. Biotechnol. Bioeng. 1980, 22, 699-734. [CrossRef]

80. Yenigün, O.; Demirel, B. Ammonia inhibition in anaerobic digestion: A review. Process Biochem. 2013, 48, 901-911. [CrossRef]

81. Chen, Y.; Cheng, J.J.; Creamer, K.S. Inhibition of anaerobic digestion process: A review. Bioresour. Technol. 2008, 99, 4044-4064. [CrossRef]

82. Zhang, C.; Yuan, Q.; Lu, Y. Inhibitory effects of ammonia on methanogen $m c r A$ transcripts in anaerobic digester sludge. FEMS Microbiol. Ecol. 2014, 87, 368-377. [CrossRef]

83. Vallee, B.L.; Ulmer, D.D. Biochemical Effects of Mercury, Cadmium, and Lead. Annu. Rev. Biochem. 1972, 41, 91-128. [CrossRef]

84. Hendriksen, H.V.; Ahring, B.K. Effects of ammonia on growth and morphology of thermophilic hydrogen-oxidizing methanogenic bacteria. FEMS Microbiol. Lett. 1991, 85, 241-246. [CrossRef] 
85. Donlon, B.A.; Razo-Flores, E.; Field, J.A.; Lettinga, G. Toxicity of N-substituted aromatics to acetoclastic methanogenic activity in granular sludge. Appl. Environ. Microbiol. 1995, 61, 3889-3893. [CrossRef] [PubMed]

86. Belay, N.; Daniels, L. Production of ethane, ethylene, and acetylene from halogenated hydrocarbons by methanogenic bacteria. Appl. Environ. Microbiol. 1987, 53, 1604-1610. [CrossRef] [PubMed]

87. Rinzema, A.; Boone, M.; van Knippenberg, K.; Lettinga, G. Bactericidal effect of long chain fatty acids in anaerobic digestion. Water Environ. Res. 1994, 66, 40-49. [CrossRef]

88. Massé, D.I.; Masse, L. Characterization of wastewater from hog slaughterhouses in Eastern Canada and evaluation of their in-plant wastewater treatment systems. Can. Agric. Eng 2000, 42, 139-146.

89. Del Pozo, R.; Diez, V. Integrated anaerobic-aerobic fixed-film reactor for slaughterhouse wastewater treatment. Water Res. 2005, 39, 1114-1122. [CrossRef] [PubMed]

90. Kayhanian, M. Performance of a high-solids anaerobic digestion process under various ammonia concentrations. J. Chem. Technol. Biotechnol. 1994, 59, 349-352. [CrossRef]

91. Da Silva, M.L.B.; Cantão, M.E.; Mezzari, M.P.; Ma, J.; Nossa, C.W. Assessment of Bacterial and Archaeal Community Structure in Swine Wastewater Treatment Processes. Microb. Ecol. 2015, 70, 77-87. [CrossRef]

92. Han, G.; Shin, S.G.; Cho, K.; Lee, J.; Kim, W.; Hwang, S. Temporal variation in bacterial and methanogenic communities of three full-scale anaerobic digesters treating swine wastewater. Environ. Sci. Pollut. Res. 2019, 26, 1217-1226. [CrossRef]

93. Del Nery, V.; Pozzi, E.; Damianovic, M.H.R.Z.; Domingues, M.R.; Zaiat, M. Granules characteristics in the vertical profile of a full-scale upflow anaerobic sludge blanket reactor treating poultry slaughterhouse wastewater. Bioresour. Technol. 2008, 99, 2018-2024. [CrossRef]

94. Shi, X.Y.; Jin, D.W.; Sun, Q.Y.; Li, W.W. Optimization of conditions for hydrogen production from brewery wastewater by anaerobic sludge using desirability function approach. Renew. Energy 2010, 35, 1493-1498. [CrossRef]

95. Granada, C.E.; Hasan, C.; Marder, M.; Konrad, O.; Vargas, L.K.; Passaglia, L.M.P.; Giongo, A.; de Oliveira, R.R.; Pereira, L.D.M.; de Jesus Trindade, F.; et al. Biogas from slaughterhouse wastewater anaerobic digestion is driven by the archaeal family Methanobacteriaceae and bacterial families Porphyromonadaceae and Tissierellaceae. Renew. Energy 2018, 118, 840-846. [CrossRef]

96. da Silva, A.M.E.V.; da Silva, R.J.N.B.; Camões, M.F.G.F.C. Optimization of the determination of chemical oxygen demand in wastewaters. Anal. Chim. Acta 2011, 699, 161-169. [CrossRef] [PubMed]

97. Maestrojuan, G.M.; Boone, D.R.; Xun, L.; Mah, R.A.; Zhang, L. Transfer of Methanogenium bourgense, Methanogenium marisnigri, Methanogenium olentangyi, and Methanogenium thermophilicum to the Genus Methanoculleus gen. nov., Emendation of Methanoculleus marisnigri and Methanogenium, and Description of New Strains of Methanoculleus bourgense and Methanoculleus marisnigri. Int. J. Syst. Bacteriol. 1990, 40, 117-122. [CrossRef]

98. Shimizu, S.; Ueno, A.; Tamamura, S.; Naganuma, T.; Kaneko, K. Methanoculleus horonobensis sp. nov., a methanogenic archaeon isolated from a deep diatomaceous shale formation. Int. J. Syst. Evol. Microbiol. 2013, 63, 4320-4323. [CrossRef]

99. Fillaudeau, L.; Blanpain-Avet, P.; Daufin, G. Water, wastewater and waste management in brewing industries. J. Clean. Prod. 2006, 14, 463-471. [CrossRef]

100. Briggs, D.E. (Ed.) Brewing: Science and Practice; Woodhead Publishing Series in Food Science and Technology; CRC Press: Boca Raton, FL, USA; Woodhead Pub. Ltd: Cambridge, UK, 2004; ISBN 978-1-85573-490-6.

101. Cronin, C.; Lo, K.V. Anaerobic treatment of brewery wastewater using UASB reactors seeded with activated sludge. Bioresour. Technol. 1998, 64, 33-38. [CrossRef]

102. Baloch, M.I.; Akunna, J.C.; Collier, P.J. The performance of a phase separated granular bed bioreactor treating brewery wastewater. Bioresour. Technol. 2007, 98, 1849-1855. [CrossRef]

103. Wu, W.M.; Hickey, R.F.; Zeikus, J.G. Characterization of metabolic performance of methanogenic granules treating brewery wastewater: Role of sulfate-reducing bacteria. Appl. Environ. Microbiol. 1991, 57, 3438-3449. [CrossRef]

104. Rotaru, A.-E.; Shrestha, P.M.; Liu, F.; Shrestha, M.; Shrestha, D.; Embree, M.; Zengler, K.; Wardman, C.; Nevin, K.P.; Lovley, D.R. A new model for electron flow during anaerobic digestion: Direct interspecies electron transfer to Methanosaeta for the reduction of carbon dioxide to methane. Energy Environ. Sci. 2014, 7, 408-415. [CrossRef] 
105. Van Haandel, A.; De Vrieze, J.; Verstraete, W.; dos Santos, V.S. Methanosaeta dominate acetoclastic methanogenesis during high-rate methane production in anaerobic reactors treating distillery wastewaters: High-rate anaerobic digestion of vinasses. J. Chem. Technol. Biotechnol. 2014, 89, 1751-1759. [CrossRef]

106. Arantes, M.K.; Alves, H.J.; Sequinel, R.; da Silva, E.A. Treatment of brewery wastewater and its use for biological production of methane and hydrogen. Int. J. Hydrog. Energy 2017, 42, 26243-26256. [CrossRef]

107. Gomec, C.; Letsiou, I.; Ozturk, I.; Eroglu, V.; Wilderer, P. Identification of Archaeal population in the granular sludge of an UASB reactor treating sewage at low temperatures. J. Environ. Sci. Health Part A Toxic Hazard. Subst. Environ. Eng. 2008, 43, 1504-1510. [CrossRef] [PubMed]

108. Martins, S.I.F.S.; Van Boekel, M.A.J.S. A kinetic model for the glucose/glycine Maillard reaction pathways. Food Chem. 2005, 90, 257-269. [CrossRef]

109. Oleszkiewicz, J.A.; Sharma, V.K. Stimulation and inhibition of anaerobic processes by heavy metals-A review. Biol. Wastes 1990, 31, 45-67. [CrossRef]

110. Agabo-García, C.; Pérez, M.; Solera, R. Adaptation of thermophilic sludge-inoculum to co-digestion with Sherry-wine distillery wastewater. Biomass Bioenergy 2020, 139, 105628. [CrossRef]

111. Oosterkamp, M.J.; Bauer, S.; Ibáñez, A.B.; Méndez-García, C.; Hong, P.-Y.; Cann, I.; Mackie, R.I. Identification of methanogenesis and syntrophy as important microbial metabolic processes for optimal thermophilic anaerobic digestion of energy cane thin stillage. Bioresour. Technol. Rep. 2019, 7, 100254. [CrossRef]

112. Town, J.R.; Links, M.G.; Fonstad, T.A.; Dumonceaux, T.J. Molecular characterization of anaerobic digester microbial communities identifies microorganisms that correlate to reactor performance. Bioresour. Technol. 2014, 151, 249-257. [CrossRef]

113. Wong, S.; Teng, T.; Ahmad, A.; Zuhairi, A.; Najafpour, G. Treatment of pulp and paper mill wastewater by polyacrylamide (PAM) in polymer induced flocculation. J. Hazard. Mater. 2006, 135, 378-388. [CrossRef]

114. Thakur, I.S. Screening and identification of microbial strains for removal of colour and adsorbable organic halogens in pulp and paper mill effluent. Process Biochem. 2004, 39, 1693-1699. [CrossRef]

115. Lacorte, S. Organic compounds in paper-mill process waters and effluents. TrAC Trends Anal. Chem. 2003, 22, 725-737. [CrossRef]

116. Patt, R.; Kordsachia, O.; Süttinger, R.; Ohtani, Y.; Hoesch, J.F.; Ehrler, P.; Eichinger, R.; Holik, H.; Hamm, U.; Rohmann, M.E.; et al. Paper and Pulp. In Ullmann's Encyclopedia of Industrial Chemistry; American Cancer Society: Atlanta, GA, USA, 2000; ISBN 978-3-527-30673-2.

117. Jantharadej, K.; Mhuantong, W.; Limpiyakorn, T.; Mongkolsuk, S.; Sirikanchana, K.; Suwannasilp, B.B. Identification of sulfate-reducing and methanogenic microbial taxa in anaerobic bioreactors from industrial wastewater treatment plants using next-generation sequencing and gene clone library analyses. J. Environ. Sci. Health Part A 2020, 55, 1-11. [CrossRef]

118. Roest, K.; Heilig, H.G.H.J.; Smidt, H.; de Vos, W.M.; Stams, A.J.M.; Akkermans, A.D.L. Community analysis of a full-scale anaerobic bioreactor treating paper mill wastewater. Syst. Appl. Microbiol. 2005, 28, 175-185. [CrossRef] [PubMed]

119. Nadais, M.H.G.A.G.; Capela, M.I.A.P.F.; Arroja, L.M.G.A.; Hung, Y.-T. Anaerobic Treatment of Milk Processing Wastewater. In Environmental Bioengineering; Wang, L.K., Tay, J.-H., Tay, S.T.L., Hung, Y.-T., Eds.; Humana Press: Totowa, NJ, USA, 2010; pp. 555-627. ISBN 978-1-58829-493-7.

120. Chartrain, M.; Zeikus, J.G. Microbial ecophysiology of whey biomethanation: Intermediary metabolism of lactose degradation in continuous culture. Appl. Environ. Microbiol. 1986, 51, 180-187. [CrossRef] [PubMed]

121. Ramsay, I.R.; Pullammanappallil, P.C. Protein degradation during anaerobic wastewater treatment: Derivation of stoichiometry. Biodegradation 2001, 12, 247-257. [CrossRef] [PubMed]

122. Suwannoppadol, S.; Ho, G.; Cord-Ruwisch, R. Overcoming sodium toxicity by utilizing grass leaves as co-substrate during the start-up of batch thermophilic anaerobic digestion. Bioresour. Technol. 2012, 125, 188-192. [CrossRef] [PubMed]

123. McAteer, P.G.; Christine Trego, A.; Thorn, C.; Mahony, T.; Abram, F.; O’Flaherty, V. Reactor configuration influences microbial community structure during high-rate, low-temperature anaerobic treatment of dairy wastewater. Bioresour. Technol. 2020, 307, 123221. [CrossRef]

124. Singh, S.; Rinta-Kanto, J.M.; Kettunen, R.; Tolvanen, H.; Lens, P.; Collins, G.; Kokko, M.; Rintala, J. Anaerobic treatment of LCFA-containing synthetic dairy wastewater at $20{ }^{\circ} \mathrm{C}$ : Process performance and microbial community dynamics. Sci. Total Environ. 2019, 691, 960-968. [CrossRef] 
125. Shahbandeh, M. Global Vegetable Oil Consumption, 2019/20. Available online: https://www.statista.com/ statistics/263937/vegetable-oils-global-consumption/ (accessed on 27 October 2020).

126. Ahmed, Y.; Yaakob, Z.; Akhtar, P.; Sopian, K. Production of biogas and performance evaluation of existing treatment processes in palm oil mill effluent (POME). Renew. Sustain. Energy Rev. 2015, 42, 1260-1278. [CrossRef]

127. Atallah, E.; Kwapinski, W.; Ahmad, M.N.; Leahy, J.J.; Zeaiter, J. Effect of water-sludge ratio and reaction time on the hydrothermal carbonization of olive oil mill wastewater treatment: Hydrochar characterization. J. Water Process Eng. 2019, 31, 100813. [CrossRef]

128. Alves, M.M.; Pereira, M.A.; Sousa, D.Z.; Cavaleiro, A.J.; Picavet, M.; Smidt, H.; Stams, A.J.M. Waste lipids to energy: How to optimize methane production from long-chain fatty acids (LCFA). Microb. Biotechnol. 2009, 2, 538-550. [CrossRef]

129. O-Thong, S.; Boe, K.; Angelidaki, I. Thermophilic anaerobic co-digestion of oil palm empty fruit bunches with palm oil mill effluent for efficient biogas production. Appl. Energy 2012, 93, 648-654. [CrossRef]

130. Doula, M.K.; Moreno-Ortego, J.L.; Tinivella, F.; Inglezakis, V.J.; Sarris, A.; Komnitsas, K. Chapter 2-Olive mill waste: Recent advances for the sustainable development of olive oil industry. In Olive Mill Waste; Galanakis, C.M., Ed.; Academic Press: Cambridge, MA, USA, 2017; pp. 29-56. ISBN 978-0-12-805314-0.

131. Miller, T.L. Methanosphaera. In Bergey's Manual of Systematics of Archaea and Bacteria; American Cancer Society: Atlanta, GA, USA, 2015; pp. 1-6. ISBN 978-1-118-96060-8.

132. McIlroy, S.J.; Kirkegaard, R.H.; McIlroy, B.; Nierychlo, M.; Kristensen, J.M.; Karst, S.M.; Albertsen, M.; Nielsen, P.H. MiDAS 2.0: An ecosystem-specific taxonomy and online database for the organisms of wastewater treatment systems expanded for anaerobic digester groups. Database (Oxford) 2017, 2017. [CrossRef] [PubMed]

133. Lin, J.; Zuo, J.; Ji, R.; Chen, X.; Liu, F.; Wang, K.; Yang, Y. Methanogenic community dynamics in anaerobic co-digestion of fruit and vegetable waste and food waste. J. Environ. Sci. 2012, 24, 1288-1294. [CrossRef]

134. Wu, Y.; Wang, C.; Liu, X.; Ma, H.; Wu, J.; Zuo, J.; Wang, K. A new method of two-phase anaerobic digestion for fruit and vegetable waste treatment. Bioresour. Technol. 2016, 211, 16-23. [CrossRef] [PubMed]

135. Nakasaki, K.; Kwon, S.H.; Ikeda, H. Identification of microorganisms in the granules generated during methane fermentation of the syrup wastewater produced while canning fruit. Process Biochem. 2013, 48, 912-919. [CrossRef]

136. USDA Citrus: World Markets and Trade. Available online: https://apps.fas.usda.gov/psdonline/circulars/ citrus.pdf (accessed on 27 October 2020).

137. Corsino, S.F.; Di Trapani, D.; Torregrossa, M.; Viviani, G. Aerobic granular sludge treating high strength citrus wastewater: Analysis of $\mathrm{pH}$ and organic loading rate effect on kinetics, performance and stability. J. Environ. Manag. 2018, 214, 23-35. [CrossRef] [PubMed]

138. Rosas-Mendoza, E.S.; Méndez-Contreras, J.M.; Martínez-Sibaja, A.; Vallejo-Cantú, N.A.; Alvarado-Lassman, A. Correction to: Anaerobic digestion of citrus industry effluents using an Anaerobic Hybrid Reactor. Clean Technol. Environ. Policy 2018, 20, 1399. [CrossRef]

139. Nasr, F.A.; Doma, H.S.; Abdel-Halim, H.S.; El-Shafai, S.A. Chemical industry wastewater treatment. Environmentalist 2007, 27, 275-286. [CrossRef]

140. Fang, H.H.P.; Chen, T.; Li, Y.-Y.; Chui, H.-K. Degradation of phenol in wastewater in an upflow anaerobic sludge blanket reactor. Water Res. 1996, 30, 1353-1360. [CrossRef]

141. Muñoz Sierra, J.D.; Oosterkamp, M.J.; Wang, W.; Spanjers, H.; van Lier, J.B. Comparative performance of upflow anaerobic sludge blanket reactor and anaerobic membrane bioreactor treating phenolic wastewater: Overcoming high salinity. Chem. Eng. J. 2019, 366, 480-490. [CrossRef]

142. Yang, Y.; Tsukahara, K.; Sawayama, S. Biodegradation and methane production from glycerol-containing synthetic wastes with fixed-bed bioreactor under mesophilic and thermophilic anaerobic conditions. Process Biochem. 2008, 43, 362-367. [CrossRef]

143. Vasconcelos, E.A.F.; Santaella, S.T.; Viana, M.B.; dos Santos, A.B.; Pinheiro, G.C.; Leitão, R.C. Composition and ecology of bacterial and archaeal communities in anaerobic reactor fed with residual glycerol. Anaerobe 2019, 59, 145-153. [CrossRef] [PubMed]

144. Wu, J.; Niu, Q.; Li, L.; Hu, Y.; Mribet, C.; Hojo, T.; Li, Y.-Y. A gradual change between methanogenesis and sulfidogenesis during a long-term UASB treatment of sulfate-rich chemical wastewater. Sci. Total Environ. 2018, 636, 168-176. [CrossRef] [PubMed] 
145. Zhang, J.; Wei, Y.; Xiao, W.; Zhou, Z.; Yan, X. Performance and spatial community succession of an anaerobic baffled reactor treating acetone-butanol-ethanol fermentation wastewater. Bioresour. Technol. 2011, 102, 7407-7414. [CrossRef]

146. Platen, H.; Schink, B. Methanogenic degradation of acetone by an enrichment culture. Arch. Microbiol. 1987, 149, 136-141. [CrossRef] [PubMed]

147. Enright, A.-M.; Collins, G.; O'Flaherty, V. Temporal microbial diversity changes in solvent-degrading anaerobic granular sludge from low-temperature $\left(15^{\circ} \mathrm{C}\right)$ wastewater treatment bioreactors. Syst. Appl. Microbiol. 2007, 30, 471-482. [CrossRef]

148. Danshita, T.; Miyaoka, Y.; Sumino, H.; Iguchi, A.; Yamaguchi, T.; Syutsubo, K. Evaluation of process performance and retained sludge properties of a psychrophilic UASB reactor for treatment of iso-plophyl alcohol (2-propanol)-containing wastewater. J. Environ. Sci. Health Part A 2018, 53, 1177-1184. [CrossRef]

Publisher's Note: MDPI stays neutral with regard to jurisdictional claims in published maps and institutional affiliations.

(C) 2020 by the authors. Licensee MDPI, Basel, Switzerland. This article is an open access article distributed under the terms and conditions of the Creative Commons Attribution (CC BY) license (http://creativecommons.org/licenses/by/4.0/). 